\title{
Magnetic $\mathrm{Fe}_{3} \mathrm{O}_{4}$-FeBNanocomposites with Promoted Cr(VI) Removal Performance
}

\author{
Wenjuan Shen,Yi Mu,Tan Xiao, and Zhihui Ai"
}

\begin{abstract}
Key Laboratory of Pesticide \& Chemical Biology of Ministry of Education, Instituteof Environmental Chemistry, Central China Normal University, Wuhan 430079, P. R. China
\end{abstract}

\begin{abstract}
In this study, amorphous $\mathrm{FeB}$ alloy modified magnetitenanocomposites $\left(\mathrm{Fe}_{3} \mathrm{O}_{4}-\mathrm{FeB}\right)$ were facilely synthesized by interfacialreduction of commercialFe ${ }_{3} \mathrm{O}_{4}$ nanoparticles with $\mathrm{NaBH}_{4}$. TEM, CS-STEM integrated with EDS, Mössbauer spectroscopyanalysis confirmed the formation of $\mathrm{Fe}_{3} \mathrm{O}_{4}-\mathrm{FeB}$, where a shell of amorphous FeB nanoparticles with 2-4 $\mathrm{nm}$ in size was surrounded on the inner magnetite $\mathrm{Fe}_{3} \mathrm{O}_{4}$ part. $\mathrm{Fe}_{3} \mathrm{O}_{4}-\mathrm{FeB}$ displayed a promotedCr(VI)removal efficiency compared withthe bare $\mathrm{Fe}_{3} \mathrm{O}_{4}$ counterpart, the interfacial reduced $\mathrm{Fe}_{3} \mathrm{O}_{4}$ nanoparticles with hydrogen and/or with hydrazine hydride. XPS analysis evidenced that reduction of $\mathrm{Cr}(\mathrm{VI})$ on surface of the $\mathrm{Fe}_{3} \mathrm{O}_{4}-\mathrm{FeB}$ was the major contribution to the $\mathrm{Cr}(\mathrm{VI})$ removal. Tafel polarization analysis of the $\mathrm{Fe}_{3} \mathrm{O}_{4}-\mathrm{FeB}$ and aqueous boron speciesmeasurement indicated thathigh $\mathrm{Cr}(\mathrm{VI})$ removal efficiencywith $\mathrm{Fe}_{3} \mathrm{O}_{4}-\mathrm{FeB}$ was highly depended on amorphous FeB alloy shell, in which boron element containing free electrons could accelerate the electron transfer from Fe to the adsorbed $\mathrm{Cr}(\mathrm{VI})$, as well reduce $\mathrm{Fe}(\mathrm{III})$ to $\mathrm{Fe}(\mathrm{II})$ and thus promote the $\mathrm{Fe}(\mathrm{III}) / \mathrm{Fe}(\mathrm{II})$ cycles. The efficient $\mathrm{Cr}(\mathrm{VI})$ removal under a wide range of $\mathrm{pH}$ values and its easy magnetic separationmake the $\mathrm{Fe}_{3} \mathrm{O}_{4}-\mathrm{FeB}$ be a potential for $\mathrm{Cr}(\mathrm{VI})$ contaminated water
\end{abstract}

\footnotetext{
* To whom correspondence should be addressed. E-mail: jennifer.ai@mail.ccnu.edu.cn. Phone/Fax: +86-27-6786 7535
} 
treatment.

KeywordsSurface modified $\mathrm{Fe}_{3} \mathrm{O}_{4} ; \mathrm{FeB}$ alloy; $\mathrm{Cr}(\mathrm{VI})$ removal; Interfacial Reduction

\section{Introduction}

The appearance of chromium in aquatic and soil systems has elicited much attention because of its potential to cause serious threat to human health [1-3]. Cr(VI)with high oxidative property is toxic to plants, animals, and human beings because of its weakadsorption on mineral/soil surfaces[1-4]. Hence, WHOand USEPAset maximum acceptable guideline concentrations of 50 and $100 \mu \mathrm{g}^{-1}$ for total chromium in drinking water respectively [5]. However,Cr(VI) concentrations in $\mathrm{Cr}(\mathrm{VI})$-bearing wastewater and $\mathrm{Cr}(\mathrm{VI})$ contaminated natural water resources are far more than the allowable threshold level [6]. Therefore, it is imperative to develop new materialsand effective methods forCr(VI)remediation.

Adsorptionis an efficient and economical technology for dealing with $\operatorname{Cr}(\mathrm{VI})$ contaminatedproblem[4-5]. $\mathrm{Fe}_{3} \mathrm{O}_{4}$ isthe most attractiveadsorbent according to its simply magnetic separable advantage compared with conventional separation [7]. The $\mathrm{Cr}(\mathrm{VI})$ adsorption process over $\mathrm{Fe}_{3} \mathrm{O}_{4}$ was considered tobe an endothermic and spontaneous process which involved reduction reaction on the surface because the ferrous ions (Fe(II)) that exists in magnetite can in theory function as reductant for $\mathrm{Cr}(\mathrm{VI})$ [7,8]. For example, Hu's research reported that structured Fe(II) in the magnetite could initiate the surface reduction of $\mathrm{Cr}(\mathrm{VI})$ to $\mathrm{Cr}(\mathrm{III})$, and subsequently chelated $\mathrm{Cr}(\mathrm{III})$ by surface hydroxyl $(-\mathrm{OH})$ groups of $\mathrm{Fe}_{3} \mathrm{O}_{4}$ to form an complex solid during the $\mathrm{Cr}(\mathrm{VI})$ removal processusing $\mathrm{Fe}_{3} \mathrm{O}_{4}$ particles as adsorbent [8]. However,Fe(II)on the surface of magnetite 
and even in the crystal lattice are not easy to release and react with $\mathrm{Cr}(\mathrm{VI})$, the $\mathrm{Fe}_{3} \mathrm{O}_{4}$ adsorbent has the disadvantage of small adsorption capacity or slow adsorption rates for $\mathrm{Cr}(\mathrm{VI})$ removal.

Therefore, a series of strategies such as functionalization, immobilization, and modification with $\mathrm{Fe}_{3} \mathrm{O}_{4}$ have been applied to realize a high efficiency of $\mathrm{Cr}(\mathrm{VI})$ removal [9-13].For instance, Jiang's groupfound the $\mathrm{HA}$ coated $\mathrm{Fe}_{3} \mathrm{O}_{4}$ adsorbent exhibited enhanced $\mathrm{Cr}(\mathrm{VI})$ removal activity and was easily separated by application of a magnetic field[11].Yuan and his coworkersdemonstrated thata ternary magnetic composite consisting of reduced graphene oxide, polypyrrole andFe ${ }_{3} \mathrm{O}_{4}$ nanoparticlescould reduce $\mathrm{Cr}(\mathrm{VI})$ to the low-toxicityCr(III) by the nitrogen species of polypyrrole [12].Additionally, $\mathrm{Xu}$ 's groupsynthesizedFe ${ }^{0}-\mathrm{Fe}_{3} \mathrm{O}_{4}$ nanocomposites embedded polyvinyl alcohol/sodium alginate beadswhich exhibited an excellent reactivity in $\mathrm{Cr}(\mathrm{VI})$ removal [13].Obviously, these modification methods of $\mathrm{Fe}_{3} \mathrm{O}_{4}$ adsorbents are complicated, and organic composites such as HA with functional groupscould cause some adverse environmental consequences [14]. More recently, it was reported thatthe doped boron could facilitate $\operatorname{Cr}(\mathrm{VI})$ reduction byboron-doped-diamond (BDD) cathodic electrodes [15], but the role of boron in $\operatorname{Cr}(\mathrm{VI})$ reduction was still unknown.

In this study,we synthesizedamorphous $\mathrm{FeB}$ alloy modified magnetite nanocomposites $\left(\mathrm{Fe}_{3} \mathrm{O}_{4}-\mathrm{FeB}\right)$ via reduction of commercial $\mathrm{Fe}_{3} \mathrm{O}_{4}$ nanoparticles with $\mathrm{NaBH}_{4}$ solution and investigated their promoted $\mathrm{Cr}(\mathrm{VI})$ removal performance. We found that amorphous $\mathrm{FeB}$ alloy was the major contribution to the high $\mathrm{Cr}(\mathrm{VI})$ removal efficiency of magnetic $\mathrm{Fe}_{3} \mathrm{O}_{4}-\mathrm{FeB}$, in which boron element containing many free electrons accelerated the electrons transfer from $\mathrm{Fe}$ to $\mathrm{Cr}(\mathrm{VI})$ as well promoted the $\mathrm{Fe}(\mathrm{III}) / \mathrm{Fe}(\mathrm{II})$ cycles. 


\section{Experimental Section}

2.1 Chemicals. Commercial $\mathrm{Fe}_{3} \mathrm{O}_{4}$ nanoparticles (50-150 $\mathrm{nm}$ in size, BET $8.82 \mathrm{~m}^{2} \cdot \mathrm{g}^{-1}$ ) was purchased from Beijing DK nano-technology Co. Ltd., China. Sodium borohydride $\left(\mathrm{NaBH}_{4}\right)$, sodium hydroxide $(\mathrm{NaOH})$, potassium dichromate $\left(\mathrm{K}_{2} \mathrm{Cr}_{2} \mathrm{O}_{7}\right)$, hydrochloric acid ( $\left.\mathrm{HCl}, 98 \%\right)$, anhydrous ethyl alcohol $\left(\mathrm{C}_{2} \mathrm{H}_{5} \mathrm{OH}\right), 1$, 10-phenanthroline $\left(\mathrm{C}_{12} \mathrm{H}_{8} \mathrm{~N}_{2} \bullet \mathrm{H}_{2} \mathrm{O}\right)$ and other reagents were obtained from National Medicines Corporation Ltd. in China. All the chemicals were of analytical grade and were used as received without further purification. High purity argon gas ( $\mathrm{Ar} \geq 99.9 \%)$ was provided by Hubei Minghui gas company, China. Deionized water was used throughout the experiment.

2.2 Preparation Procedure.FeB alloy modified magnetitenanocomposites $\left(\mathrm{Fe}_{3} \mathrm{O}_{4}-\mathrm{FeB}\right)$ were synthesized by treating commercialFe $\mathrm{O}_{4}$ nanoparticles with $\mathrm{NaBH}_{4}$ solution. In a typical procedure, $\mathrm{NaBH}_{4}$ solution with a concentration of $0.34 \mathrm{~mol} \cdot \mathrm{L}^{-1}$ was prepared by dissolving $0.65 \mathrm{~g}$ of $\mathrm{NaBH}_{4}$ in $50 \mathrm{~mL}$ of deionized water. Then, $0.1 \mathrm{~g} \mathrm{Fe}_{3} \mathrm{O}_{4}$ powders was added into the $\mathrm{NaBH}_{4}$ solution to initiate the reactive reaction of $\mathrm{Fe}_{3} \mathrm{O}_{4}$ and $\mathrm{NaBH}_{4}$, the suspension was mechanically stirred for $4 \mathrm{~h}$ and then centrifuged (5000 rmp for 5 minutes), the powders were obtained via vacuum filter and washed with deionized water and ethanol and finally dried under argon flow. All the samples were stored in the argon bubbled oxygen-free vials to prevent them from being oxidized. For comparison, counterpart samples were obtained by adjusting the initial concentration of $\mathrm{NaBH}_{4}$ solution $\left(0.085 \sim 1.36 \mathrm{~mol} \cdot \mathrm{L}^{-1}\right)$ and/or the reaction time $(0.5 \mathrm{~h} \sim 5 \mathrm{~h})$. Twosurface modified $\mathrm{Fe}_{3} \mathrm{O}_{4}$ counterparts were synthesized by reduction of the commercial $\mathrm{Fe}_{3} \mathrm{O}_{4}$ nanoparticles in gaseous $\mathrm{H}_{2}\left(3 \% \mathrm{H}_{2} / 97 \% \mathrm{Ar}\right)\left(\mathrm{Fe}_{3} \mathrm{O}_{4}-\mathrm{H}_{2}\right)$ and/or via reductive precipitation with hydrazine hydride $\left(\mathrm{N}_{2} \mathrm{H}_{4} \cdot \mathrm{H}_{2} \mathrm{O}\right)$ solutionobtained by diluting 2 mLof $\mathrm{N}_{2} \mathrm{H}_{4} \cdot \mathrm{H}_{2} \mathrm{O}(85 \%)\left(\mathrm{Fe}_{3} \mathrm{O}_{4}-\mathrm{N}_{2} \mathrm{H}_{4} \cdot \mathrm{H}_{2} \mathrm{O}\right)$ in $40 \mathrm{~mL} \mathrm{H}_{2} \mathrm{O}$.

2.3 Characterizations. X-ray diffraction (XRD) was determined with a Bruker D8 Advance X-ray 
diffractometer with $\mathrm{Cu} \mathrm{Ka}$ radiation $(\lambda=1.54178 \AA)$ at a scanning rate of $2^{\circ} \min ^{-1}$ in the $2 \theta$ range from $15^{\circ}$ to $70^{\circ}$. Surface morphology characterization of the $\mathrm{Fe}_{3} \mathrm{O}_{4}, \mathrm{Fe}_{3} \mathrm{O}_{4}-\mathrm{FeB}$ nanocomposites before and after $\mathrm{Cr}(\mathrm{VI})$ removal was performed on a LEO 1450VP scanning electron microscope (SEM). Transmission electron microscopy (TEM) was carried on a JEOL JEM-2010 electron microscope operating at $200 \mathrm{kV}$. The samples for TEM were prepared by dispersing the final powders in ethanol; the dispersion was then dropped on carbon-copper grids. Furthermore, the obtained powders deposited on a copper grid were observed by a high-resolution transmission electron microscope (HRTEM). The energy-filtered transmission electron microscopy (EF-TEM) was performed with JEM-ARM200F (GIF quantum 965). X-ray photoelectron spectroscopy (XPS) was recorded with a Kratos ASIS-HS X-ray photoelectron spectroscope equipped with a standard and monochromatic source operated at $150 \mathrm{~W}(15 \mathrm{kV}, 10 \mathrm{~mA})$. BET (Brunauer-Emmett-Teller) surface areaswere determined from $\mathrm{N}_{2}$ physisorption with an RXM-100 advanced catalyst characterization system (ASDI, Inc) using the BJH (Barrett-Joyner-Halenda) and multi-point BET methods. Magnetic hysteresis loops were obtained for the evaluation of their saturation magnetism (Ms), remanence $(\mathrm{Mr})$, and coercivity $(\mathrm{Hc})$ by a vibrating sample magnetometer (VSM, Lake Shore 7307). Mössbauer spectra was recorded using a ${ }^{57} \mathrm{Co}^{*}: \mathrm{Rh} \gamma$-ray source $\left(\mathrm{E}_{0}=14.4 \mathrm{keV}\right)$ mounted on an electromagnetic drive with a triangular velocity signal. The spectra were least-squares fitted to get the hyperfine parameters (isomer shift $\delta$, quadrupolar splitting $\mathrm{Q}$, and hyperfine filed $\mathrm{H}$ ), the broad hyperfine filed distribution was fitted using a histogram of hyperfine filed with free weights.

$2.4 \mathrm{Cr}(\mathrm{VI})$ Removal Setup. $1000 \mathrm{mg} \cdot \mathrm{L}^{-1}$ of $\mathrm{Cr}$ (VI) stock solutionwas prepared by dissolving $1.4114 \mathrm{~g}$ of $\mathrm{K}_{2} \mathrm{Cr}_{2} \mathrm{O}_{7}$ in $500 \mathrm{~mL}$ deionized water. The $\mathrm{Cr}$ (VI) solution with different initial concentrations was prepared by dilution of the stock $\mathrm{K}_{2} \mathrm{Cr}_{2} \mathrm{O}_{7}$ standard solution with deionized water. 
All the experiments were carried out in $100 \mathrm{~mL}$ conical beakers containing $40 \mathrm{~mL}$ of $\mathrm{Cr}(\mathrm{VI})$ solution at $25^{\circ} \mathrm{C}$. During a typical $\mathrm{Cr}(\mathrm{VI})$ removal process, $0.032 \mathrm{~g}$ of $\mathrm{Fe}_{3} \mathrm{O}_{4}$ or surface modified $\mathrm{Fe}_{3} \mathrm{O}_{4}$ powders was added into the conical beaker with $40 \mathrm{~mL}$ of $\mathrm{Cr}(\mathrm{VI})$ solution $\left(8 \mathrm{mg} \cdot \mathrm{L}^{-1}\right)$. The beakerwas sealed with rubber screw caps and then transferred into a shaker (HY-5 Rotary shaker, China) with a speed of $200 \mathrm{rpm}$ to initiate the removal process. The initial $\mathrm{pH}$ of the $\mathrm{Cr}(\mathrm{VI})$ solution was 6.3 without adjusting. In some case, the initial $\mathrm{pH}$ of $\mathrm{Cr}(\mathrm{VI})$ solution was adjusted to 2.0 and 10.0 with $0.1 \mathrm{~mol} \cdot \mathrm{L}^{-1}$ of $\mathrm{HCl}$ and $0.1 \mathrm{~mol} \cdot \mathrm{L}^{-1} \mathrm{NaOH}$ respectively. The $\mathrm{Cr}(\mathrm{VI})$ solution samples were collected by a $5 \mathrm{~mL}$ syringe at regular intervalsand filtered immediately through a $0.45 \mu \mathrm{m}$ nylon syringe filter for the measurement of $\mathrm{Cr}(\mathrm{VI})$ concentration. The influence of 1,10-phenanthroline on the $\operatorname{Cr}(\mathrm{VI})$ removal was conducted by adding $3 \mathrm{~g} \cdot \mathrm{L}^{-1}$ of 1,10 -phenanthroline to the $\mathrm{Cr}(\mathrm{VI})$ aqueous solution before introducing the sample powders. After the $\mathrm{Cr}(\mathrm{VI})$ removal process, the suspension was transferred to a centrifuge tube and then centrifuged (8000 rmp for 5 minutes using an Eppendorf 5840R Centrifuge) to remove the nanoparticles from the supernatant. The used powders were dried under Ar gas flow for further characterizations.

2.5 Analysis Methods. The concentration of $\mathrm{Cr}(\mathrm{VI})$ in aqueous solution was measured by using 1,5-diphenylcarbazide method [16]. This method is not sensitive to $\mathrm{Cr}$ (III) species. Chromium reagent 1,5-diphenylcarbazide was mixed with $5 \mathrm{~mL}$ of filtrate for $5 \mathrm{~min}$. The absorbance of generated $\mathrm{Cr}(\mathrm{VI})$-diphenylcarbazide product was determined by using a UV-vis spectrometer (UV-2550, Shimadzu, Japan) at a wavelength of $541 \mathrm{~nm}$. Total chromium $(\mathrm{Cr}(\mathrm{VI})$ and $\mathrm{Cr}(\mathrm{III}))$ in solution was measured with a flame-atomic absorption spectrometer (Flame-AAS, 5100, PerkinElmer, USA).The concentration ofFe(II) was determined with 1,10-phenanthroline method by using UV-vis spectrophotometer (UV-2550, Shimadzu, Japan) at a wavelength of $510 \mathrm{~nm}$ [17]. The 
$\mathrm{Fe}$ (II) standard solutions were prepared from anhydrous ferrous chloride solution $\left(\mathrm{FeCl}_{2}, 99.9 \%\right)$.

Total Fe was determined by atomic absorption spectrophotometer (AAS).B elemental analysis was carried out using inductively coupled plasma atomic emission spectroscopy (ICP-AES) at wavelengths of $249.77 \mathrm{~nm}$. The $\mathrm{pH}$ of the solution was measured at the same regular intervals during the $\mathrm{Cr}(\mathrm{VI})$ removal.Electrochemical experiments were performed by a CHI-660B electrochemical system (Shanghai, China) at room temperature. Tafel scans were performed to measure the free corrosion potentials. The work electrode made of $5 \mathrm{mg}$ samples was placed in $50 \mathrm{~mL}$ of $50 \mathrm{mmol} \cdot \mathrm{L}^{-1}$ $\mathrm{Na}_{2} \mathrm{SO}_{4}$ electrolyte solution in a $100 \mathrm{~mL}$ beaker containing a calomel reference electrode and a $\mathrm{Pt}$ counter electrode. All the Tafel diagrams were obtained by polarizing the work electrodes $\pm 200 \mathrm{mV}$ with respect to their open circuit potentials. All the potentials in the Tafel diagrams were with respect to the standard hydrogen electrode (SHE).

\section{Results and Discussion}

3.1 Characterizations. SEM images indicated that both the commercial $\mathrm{Fe}_{3} \mathrm{O}_{4}$ and the $\mathrm{NaBH}_{4}$ treated $\mathrm{Fe}_{3} \mathrm{O}_{4}$ were irregular nanoparticles in size of $80-150 \mathrm{~nm}$, the morphology of nanoparticles did not change after the $\mathrm{NaBH}_{4}$ treatment (Figure 1a and 1b). XRD patterns suggested that the phase and crystalline ofthe commercial $\mathrm{Fe}_{3} \mathrm{O}_{4}$ and the $\mathrm{NaBH}_{4}$ treated $\mathrm{Fe}_{3} \mathrm{O}_{4}$ were all indexed to cubic $\mathrm{Fe}_{3} \mathrm{O}_{4}$ (JCPDS file No. 19-0629) (Figure 1c) [18]. However, the BET surface areas of the $\mathrm{Fe}_{3} \mathrm{O}_{4}$ nanoparticles increased from $8.8 \mathrm{~m}^{2} \cdot \mathrm{g}^{-1}$ to $15.4 \mathrm{~m}^{2} \cdot \mathrm{g}^{-1}$ after the $\mathrm{NaBH}_{4}$ treatment (Figure 1d), suggesting that the reaction of $\mathrm{Fe}_{3} \mathrm{O}_{4}$ and $\mathrm{NaBH}_{4}$ happened and the $\mathrm{NaBH}_{4}$ treatment could change the superficial structure of $\mathrm{Fe}_{3} \mathrm{O}_{4}$ nanoparticles.

TEM images confirmed $\mathrm{Fe}_{3} \mathrm{O}_{4}$ before and after $\mathrm{NaBH}_{4}$ reaction were all nanoparticles with the 
sizes in the range of $80-150 \mathrm{~nm}$ (Figure 2a, 2d), this is consistent with the SEM results. Higher magnification TEM images showed that the surface of the commercial $\mathrm{Fe}_{3} \mathrm{O}_{4}$ was smooth (Figure 2b), on contrast, $\mathrm{NaBH}_{4}$ treated $\mathrm{Fe}_{3} \mathrm{O}_{4}$ nanoparticles exhibited an uneven surface where many tiny particles were observed (Figure 2e), this could explain the increased BET surface areas after the reduction by $\mathrm{NaBH}_{4}$. HRTEM analysis further revealed the single-crystal nature of the $\mathrm{Fe}_{3} \mathrm{O}_{4}$ nanoparticles before and after $\mathrm{NaBH}_{4}$ treatment (Figure 2c, 2f), a lattice spacing of $0.296 \mathrm{~nm}$ wascorresponding to the distance between (220) crystal planes of cubic $\mathrm{Fe}_{3} \mathrm{O}_{4}(\mathrm{JCPDS}$ file No. 19-0629) $[19,20]$.The TEM and HRTEM results confirmed the superficial reaction between $\mathrm{Fe}_{3} \mathrm{O}_{4}$ and $\mathrm{NaBH}_{4}$, this agreed with the BET analysis.

Moreover, the morphology and composition of $\mathrm{Fe}_{3} \mathrm{O}_{4}$ nanoparticles before and after $\mathrm{NaBH}_{4}$ treatment were investigated by EF-TEM and element mapping analysis (Figure 3). The commercial $\mathrm{Fe}_{3} \mathrm{O}_{4}$ was with smooth surface (Figure 3a), while an uneven surface with numerous nanoparticles was observed in the $\mathrm{NaBH}_{4}$ treated $\mathrm{Fe}_{3} \mathrm{O}_{4}$ sample (Figure 3e). The EF-TEM element mapping analysisindicated that $\mathrm{Fe}$ and $\mathrm{O}$ elementswere observed in the bare $\mathrm{Fe}_{3} \mathrm{O}_{4}$ (Figure $3 \mathrm{~b}$ and $3 \mathrm{c}$ ) and $\mathrm{NaBH}_{4}$ treated $\mathrm{Fe}_{3} \mathrm{O}_{4}$ nanoparticles (Figure 3f and 3g). The bare $\mathrm{Fe}_{3} \mathrm{O}_{4}$ was free of boron element (Figure 3d), interestingly, homo-distributed boron element wasonly found $\mathrm{inFe}_{3} \mathrm{O}_{4}$ sample after $\mathrm{NaBH}_{4}$ reduction (Figure 3h). This result suggested tiny nanoparticles containing B element were formed on the surface of the $\mathrm{NaBH}_{4}$ treated $\mathrm{Fe}_{3} \mathrm{O}_{4}$. The boron was not distinguished by XRD, TEM, and HRTEM analysis because of its amorphous nature.

The crystallite size was also determined from the diffraction peaks using the Scherer formula (Eq. 1), and interplanar spacing $d_{h k l}$ was determined by Bragg's law (Eq. 2)

$$
D=\frac{K \bullet \lambda}{\omega \cdot \cos \theta}
$$




$$
d_{h k l}=\frac{\lambda}{2 \operatorname{Sin} \theta}(2)
$$

Where $D$ is the crystallite size $(\mathrm{nm}), \lambda$ is the wavelength of the monochromatic $\mathrm{X}$-ray beam $(0.154056 \mathrm{~nm}), \omega$ is the full width at half-maximum (FWHM) value of X-ray diffraction lines under consideration (see Fig. 1c), $K$ is a constant (equal to 0.9 ), and $\theta$ is the half diffraction angle of $2 \theta$ (degree). The particle size and interplanar spacing $d_{h k l}$ of commercial $\mathrm{Fe}_{3} \mathrm{O}_{4}$ and $\mathrm{Fe}_{3} \mathrm{O}_{4}-\mathrm{FeB}$ are determined at the peak D220, the particle size were calculated to be $110.2 \mathrm{~nm}$ for commercial $\mathrm{Fe}_{3} \mathrm{O}_{4}$ and $105.6 \mathrm{~nm}$ for $\mathrm{Fe}_{3} \mathrm{O}_{4}-\mathrm{FeB}$ respectively, these values are slightly smaller than those obtained from TEM analysis.

Furthermore, ${ }^{57} \mathrm{Fe}$ Mössbauer spectroscopy spectra of the $\mathrm{Fe}_{3} \mathrm{O}_{4}$ before and after $\mathrm{NaBH}_{4}$ treatment were recorded at $300 \mathrm{~K}$ (Figure 4). Mössbauer spectrumof the bare $\mathrm{Fe}_{3} \mathrm{O}_{4}$ was fit with two sextets which could be ascribed to paramagnetic high-spin iron(II) and iron(III)in $\mathrm{Fe}_{3} \mathrm{O}_{4}$ (the corresponding hyperfine parameterswere shown in Table 1) [21].Besides the two sextets related to $\mathrm{Fe}_{3} \mathrm{O}_{4}$, the $\mathrm{NaBH}_{4}$ treated $\mathrm{Fe}_{3} \mathrm{O}_{4}$ nanoparticles exhibited two broad peaks, whichwere assigned to poor crystallinity and/or nonhomogeneous composition of the FeB alloy [21-24],implying that the tiny particles formed on the surface of $\mathrm{Fe}_{3} \mathrm{O}_{4}$ could be amorphous $\mathrm{FeB}$ alloys.

XPS spectra were further recorded and analyzed (Figure 5). B element was observed in the $\mathrm{NaBH}_{4}$ treated $\mathrm{Fe}_{3} \mathrm{O}_{4}$ sample besides the elements of $\mathrm{Fe}, \mathrm{O}$, and $\mathrm{C}$ found in the bare $\mathrm{Fe}_{3} \mathrm{O}_{4}$ (Figure 5a), where the $\mathrm{C} 1 \mathrm{~s}$ peak at $284.5 \mathrm{eV}$ could be attributed to the adventitious carbon on the surface of the samples. The peaks at 710.1 and 719.0 eVrelated to Fe(II) and the shoulder peak at $724.4 \mathrm{eVassigned}$ to $\mathrm{Fe}$ (III) suggested the co-existence of $\mathrm{Fe}$ (III) and $\mathrm{Fe}(\mathrm{II})$ in the bare and $\mathrm{NaBH}_{4}$ treated $\mathrm{Fe}_{3} \mathrm{O}_{4}$ (Figure 5b) [24-26]. The calculation of the peak area in core level spectra of $\mathrm{Fe} 2 \mathrm{p}$ gave a ratio of ferrous iron to total iron $\left(\mathrm{Fe}^{\mathrm{II}} / \mathrm{Fe}_{\text {total }}\right)$ and ferric iron to total iron $\left(\mathrm{Fe}^{\mathrm{III}} / \mathrm{Fe}_{\text {total }}\right)(\mathrm{Table} 2)$. It was found 
that the value of $\mathrm{Fe}^{\mathrm{II}} / \mathrm{Fe}_{\text {total }}$ increased from 0.395 to 0.570 after the $\mathrm{NaBH}_{4}$ treatment, indicating that the amount of ferrous ions on the surface increased with the $\mathrm{NaBH}_{4}$ reduction. The high resolution $\mathrm{B}$ 1s XPS spectra were compared (Figure 5c), the peak in 191.5 and $187.6 \mathrm{eV}$ can be attributed to the oxidized boron species and elemental Bin FeBon the $\mathrm{NaBH}_{4}$ treated $\mathrm{Fe}_{3} \mathrm{O}_{4}$ respectively. It was observed that the binding energy of elemental B in FeB positively shifted about 0.3 eVin comparison with pure boron $(187.3 \mathrm{eV})$, indicating electron transfer from boron to iron happened in FeBalloys [27-28]. Therefore, on the base of EF-TEM element mapping result, ${ }^{57} \mathrm{Fe}$ Mössbauer spectroscopy analysis, and XPS result, wecan reasonably deduce that amorphous FeB alloy modified magnetitenanocomposites $\left(\mathrm{Fe}_{3} \mathrm{O}_{4}-\mathrm{FeB}\right)$ were facilely synthesized by interfacialreduction of commercialFe $\mathrm{O}_{4}$ nanoparticleswith $\mathrm{NaBH}_{4}$ solution.

3.2 Removal of $\mathrm{Cr}(\mathrm{VI})$ withFe $\mathrm{O}_{3} \mathrm{O}_{4} \mathrm{FeB}$ Nanocomposites. The as-prepared $\mathrm{Fe}_{3} \mathrm{O}_{4}-\mathrm{FeB}$ was used for the removal of aqueous $\mathrm{Cr}(\mathrm{VI})$ at neutral $\mathrm{pH}$ of 6.3 (Figure 6). It was observedthat $\mathrm{Cr}(\mathrm{VI})$ removal was only $5 \%$ with the bare commercial $\mathrm{Fe}_{3} \mathrm{O}_{4}$, however, the removal efficiency reached to $9 \%$, $85 \%$, and $100 \%$ with the $\mathrm{Fe}_{3} \mathrm{O}_{4}-\mathrm{FeB}$ obtained after $\mathrm{NaBH}_{4}$ treatment for 1, 2, and after $3 \mathrm{~h}$ respectively within 30 min (Figure 6a). $\mathrm{Cr}(\mathrm{VI})$ removal efficiency with $\mathrm{Fe}_{3} \mathrm{O}_{4}-\mathrm{FeB}$ first increased with prolonging reaction time from 0 to $4 \mathrm{~h}$, and then kept constancy when the reaction time was more than $4 \mathrm{~h}$. The removal was found to obey a pseudo first-order reaction kinetic equation with high correlation coefficients (Figures 6b). The apparent Cr(VI) removal rate constants $(k)$ were calculated to be 0.01 , 0.06, 0.19, 0.27, and $0.28 \mathrm{~min}^{-1}$ for $\mathrm{Fe}_{3} \mathrm{O}_{4}-\mathrm{FeB}$ obtained at 1, 2, 3, 4, and $5 \mathrm{~h}$, respectively. Moreover, it was found that the $\mathrm{Cr}(\mathrm{VI})$ removal efficiency increased with the initial concentrations of the $\mathrm{NaBH}_{4}$ solution (Figure 6c), the apparent $\mathrm{Cr}(\mathrm{VI})$ removal rate constant reached to the highest value of $0.27 \mathrm{~min}^{-1}$ when concentration of $\mathrm{NaBH}_{4}$ was $0.34 \mathrm{~mol} \cdot \mathrm{L}^{-1}$ (Figure 6d). Thus the $\mathrm{Fe}_{3} \mathrm{O}_{4}-\mathrm{FeB}$ 
obtained with $0.34 \mathrm{~mol} \cdot \mathrm{L}^{-1}$ of $\mathrm{NaBH}_{4}$ for $4 \mathrm{~h}$ was used in the following mechanistic investigation.

It is expected that both adsorption and reduction of $\mathrm{Cr}(\mathrm{VI})$ co-happen with $\mathrm{Fe}_{3} \mathrm{O}_{4}-\mathrm{FeB}$ due to its high BET surface area $\left(15.4 \mathrm{~m}^{2} \cdot \mathrm{g}^{-1}\right)$ and strong electron donor nature of FeB. The adsorption process induced by electrostatic, hydrophobic and hydrogen bond interaction depends strongly on solution $\mathrm{pH}$ values, because $\mathrm{pH}$ could determine the surface charge of $\mathrm{Fe}_{3} \mathrm{O}_{4}-\mathrm{FeB}$ and the form of $\mathrm{Cr}(\mathrm{VI})$ species. $\mathrm{HCrO}_{4}{ }^{-}$is the dominant species between $\mathrm{pH} 2$ and 6; the form shifts to $\mathrm{CrO}_{4}{ }^{2-}$ and $\mathrm{Cr}_{2} \mathrm{O}_{7}{ }^{2-}$ if $\mathrm{pH}$ rises to above 6 , and $\mathrm{CrO}_{4}{ }^{2-}$ is the only existence when $\mathrm{pH}>7.5$. We found that $\mathrm{Fe}_{3} \mathrm{O}_{4}-\mathrm{FeB}$ could realize totally $\mathrm{Cr}(\mathrm{VI})$ removal in $20 \mathrm{~min}$ at a broad $\mathrm{pH}$ range from 2-10 (Figure 7a), because the positive surface charge makes it easier to attract the negative $\mathrm{Cr}(\mathrm{VI})$ species when $\mathrm{pH}$ is under the $\mathrm{pH}$ of zero point charge (Figure $7 \mathrm{~b}$ ) [5]. Moreover, the effect of initial $\mathrm{Cr}(\mathrm{VI})$ concentrations(4-32 $\mathrm{mg} \bullet \mathrm{L}^{-1}$ ) on $\mathrm{Cr}(\mathrm{VI})$ removal with $\mathrm{Fe}_{3} \mathrm{O}_{4}-\mathrm{FeB}$ was investigated (Figure $7 \mathrm{c}$ ). $\mathrm{Cr}$ (VI) removal efficiency reached $100 \%$ within $1.5 \mathrm{~h}$ when $\mathrm{Cr}(\mathrm{VI})_{\text {initial }}$ was of $4,8,16$, and $32 \mathrm{mg} \cdot \mathrm{L}^{-1}$, the amount of $\mathrm{Cr}(\mathrm{VI})$ absorbed per unit mass of the adsorbentwas evaluated by using the mass balance equation (Eqs. 3-4) [4].

$$
\begin{aligned}
& q_{t}=\left[\left(C_{0}-C_{t}\right) V\right] / W(3) \\
& t / q_{t}=1 /\left(k_{1} q_{e}^{2}\right)+t / q_{e}\left(k_{0}=k_{1} q_{e}^{2}\right)
\end{aligned}
$$

Where ${ }^{q_{t}}\left(\mathrm{mg}^{\bullet} \mathrm{g}^{-1}\right)$ is the amount of $\mathrm{Cr}(\mathrm{VI})$ adsorbed per gram of adsorbent at time ${ }^{t}(\mathrm{~min}), C_{0}$ is the initial concentration of $\mathrm{Cr}(\mathrm{VI})$ in the solution $\left(\mathrm{mg} \cdot \mathrm{L}^{-1}\right), \quad C_{t}$ is the concentration of $\mathrm{Cr}(\mathrm{VI})$ at time $t$ of adsorption $\left(\mathrm{mg} \cdot \mathrm{L}^{-1}\right), W$ is the mass of the adsorbent used $(\mathrm{g})$, and $V$ the volume of the solution $(\mathrm{L}), k_{1}\left(\mathrm{~g} \cdot \mathrm{mg}^{-1} \cdot \mathrm{min}^{-1}\right)$ is the rate constant of the pseudo-second-order model of adsorption, and $k_{0}\left(\mathrm{mg} \cdot \mathrm{g}^{-1} \mathrm{~min}^{-1}\right)$ is the initial adsorption rate. The maximum $\mathrm{Cr}(\mathrm{VI})$ adsorption capacity of the $\mathrm{Fe}_{3} \mathrm{O}_{4}-\mathrm{FeB}$ was found to be $10.04 \mathrm{mg} \bullet \mathrm{g}^{-1}$ (Figure $7 \mathrm{~d}$ and Table 3), which was even higher than that of 
the $\mathrm{Fe} @ \mathrm{Fe}_{2} \mathrm{O}_{3}$ nanowires previous reported $\left(7.78 \mathrm{mg}^{\circ} \mathrm{g}^{-1}\right)$ withan initial $\mathrm{Cr}(\mathrm{VI})$ concentration of 8.0 $\mathrm{mg} \bullet \mathrm{L}^{-1}$ [4] and other common used adsorbents (Table 4), suggesting the highCr(VI) removal efficiency with the as-prepared $\mathrm{Fe}_{3} \mathrm{O}_{4}-\mathrm{FeB}$.

To get mechanistic information on the adsorption of $\mathrm{Fe}_{3} \mathrm{O}_{4}-\mathrm{FeB}$, Langmuir isotherm and Freundlich isotherm models were used to fit the data. The Langmuir isotherm model is applicable for monolayer adsorption on a surface containing a finite number of binding sites. The linear form of Langmuir equation is written as Eq. 5:

$$
\frac{\mathrm{C}_{\mathrm{t}}}{\mathrm{q}_{\mathrm{t}}}=\frac{1}{\mathrm{Q}^{0} \mathrm{~b}}+\frac{\mathrm{C}_{\mathrm{t}}}{\mathrm{Q}^{0}}
$$

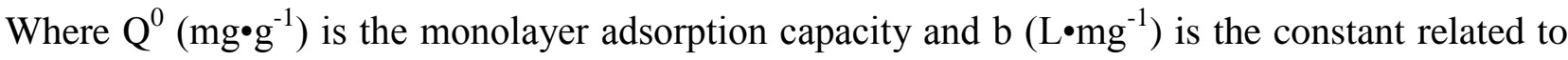
the energy of adsorption.

The Freundlich isotherm model, which is based on the assumption that the adsorption occurs on a heterogeneous adsorbent surface [32], can be represented as Eq 6:

$$
\ln q_{t}=\ln K_{f}+\frac{1}{n} \ln C_{t}
$$

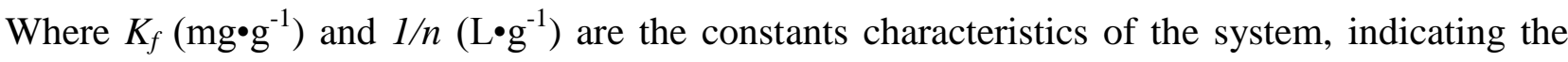
adsorption capacity of the sorbent and the intensity of the adsorption.

The linear plots of $C_{t} / q_{t}$ versus $C_{t}$ (Langmuir plot) and $\ln q_{t}$ versus $\ln C_{t}$ (Freundlich plot) were drawn at four different concentration of $\operatorname{Cr}(\mathrm{VI})\left(4,8,16,32 \mathrm{mg} \cdot \mathrm{L}^{-1}\right)$ (figures not shown), and $Q_{0}, K$, $K_{f}, n$ of Langmuir and Freundlich model parameters are shown in Table 5. The regression coefficients for Langmuir $\left(\mathrm{R}^{2}>0.99\right)$ were higher than those for Freundlich model $\left(0.79<\mathrm{R}^{2}<0.91\right)$, indicating a better fitting with the Freundlich model.

In general, $\mathrm{Cr}(\mathrm{VI})$ removal with the $\mathrm{Fe}_{3} \mathrm{O}_{4}-\mathrm{FeB}$ is related to physical adsorptive process and chemical reductive reactions, in which both iron $(\mathrm{Fe})$ and boron $(\mathrm{B})$ in the $\mathrm{FeB}$ alloys could react 
with $\mathrm{Cr}(\mathrm{VI})$. As the bare $\mathrm{Fe}_{3} \mathrm{O}_{4}$ nanoparticles could not remove $\mathrm{Cr}(\mathrm{VI})$ (Figure 6a), we deduced that the chemical reactions of $\mathrm{Cr}(\mathrm{VI})$ and $\mathrm{FeB}$ alloys dominated $\mathrm{Cr}(\mathrm{VI})$ removal process with $\mathrm{Fe}_{3} \mathrm{O}_{4}$-FeB.In order to convince this deduction, we prepared two interfacial reduced $\mathrm{Fe}_{3} \mathrm{O}_{4}$ powders which were $\mathrm{Fe}_{3} \mathrm{O}_{4}$ treated by hydrogen $\left(\mathrm{H}_{2} / \mathrm{Ar}\right)\left(\mathrm{Fe}_{3} \mathrm{O}_{4}-\mathrm{H}_{2}\right)$ andhydrazine hydride $\left(\mathrm{N}_{2} \mathrm{H}_{4} \bullet \mathrm{H}_{2} \mathrm{O}\right)$ $\left(\mathrm{Fe}_{3} \mathrm{O}_{4}-\mathrm{N}_{2} \mathrm{H}_{4} \cdot \mathrm{H}_{2} \mathrm{O}\right)$ respectively. The $\mathrm{Fe}_{3} \mathrm{O}_{4}-\mathrm{H}_{2}$ and $\mathrm{Fe}_{3} \mathrm{O}_{4}-\mathrm{N}_{2} \mathrm{H}_{4} \cdot \mathrm{H}_{2} \mathrm{O}$ showed a similar morphology to commercial $\mathrm{Fe}_{3} \mathrm{O}_{4}$ nanoparticles (Figure $8 \mathrm{a}$ and $8 \mathrm{~b}$ ). XRD patterns of the $\mathrm{Fe}_{3} \mathrm{O}_{4}-\mathrm{H}_{2}$ and $\mathrm{Fe}_{3} \mathrm{O}_{4}-\mathrm{N}_{2} \mathrm{H}_{4} \cdot \mathrm{H}_{2} \mathrm{O}$ samples suggested that hydrogen treatment and hydrazine hydride treatment could not change the phase and crystalline $\mathrm{ofFe}_{3} \mathrm{O}_{4}$ (Figure 8c). High resolution Fe 2p XPS spectra confirmed the formation of $\mathrm{Fe}(\mathrm{II})$ on the surface of the $\mathrm{Fe}_{3} \mathrm{O}_{4}-\mathrm{H}_{2}$ and $\mathrm{Fe}_{3} \mathrm{O}_{4}-\mathrm{N}_{2} \mathrm{H}_{4} \bullet \mathrm{H}_{2} \mathrm{O}$ samples (Figure 8d), where $\mathrm{Fe}^{\mathrm{II}} / \mathrm{Fe}_{\text {total }}$ ratiosof the $\mathrm{Fe}_{3} \mathrm{O}_{4}-\mathrm{N}_{2} \mathrm{H}_{4} \cdot \mathrm{H}_{2} \mathrm{O}(0.546)$ and $\mathrm{Fe}_{3} \mathrm{O}_{4}-\mathrm{H}_{2}(0.486)$ were much higher than that of the bare commercial $\mathrm{Fe}_{3} \mathrm{O}_{4}(0.395)$, indicating that superficial reduction happened after treating $\mathrm{Fe}_{3} \mathrm{O}_{4}$ withN $\mathrm{N}_{2} \mathrm{H}_{4} \bullet \mathrm{H}_{2} \mathrm{O}$ and $\mathrm{H}_{2}$ /Ar. However, we found that $\mathrm{Cr}(\mathrm{VI})$ removal was not increased with $\mathrm{Fe}_{3} \mathrm{O}_{4}-\mathrm{H}_{2}$ and $\mathrm{Fe}_{3} \mathrm{O}_{4}-\mathrm{N}_{2} \mathrm{H}_{4} \cdot \mathrm{H}_{2} \mathrm{O}$ compared with the commercial $\mathrm{Fe}_{3} \mathrm{O}_{4}$ (Figure 9), indication that $\mathrm{B}$ element in the $\mathrm{Fe}_{3} \mathrm{O}_{4}-\mathrm{FeB}$ played key role on their effective $\mathrm{Cr}(\mathrm{VI})$ removal performance.

3.3 Role of $\mathrm{B}$ in $\mathrm{Cr}(\mathrm{VI})$ Removal with $\mathrm{Fe}_{3} \mathrm{O}_{4}-\mathrm{FeB}$ Nanocomposites. To understand the role of $\mathrm{B}$ element on $\mathrm{Cr}(\mathrm{VI})$ removal with the $\mathrm{Fe}_{3} \mathrm{O}_{4}-\mathrm{FeB}$, we measuredconcentrations of dissolved $\mathrm{B}$ species, $\mathrm{Fe}(\mathrm{II})$, and $\mathrm{Fe}(\mathrm{III})$ in solution during the removal process (Figure 10). It was observed that Fe(II)ions and $\mathrm{B}$ species were continuouslyreleased to the anoxic aqueous solution, the concentration of aqueous $\mathrm{B}$ species and $\mathrm{Fe}(\mathrm{II})$ increased to 14.14 and $15.03 \mathrm{mg} \cdot \mathrm{L}^{-1}$ respectively within $30 \mathrm{~min}$, implying that B element and $\mathrm{Fe}$ in the FeB alloy involved in $\mathrm{Cr}(\mathrm{VI})$ removal. We did not detect any soluble $\mathrm{Fe}(\mathrm{III})$ species duringCr(VI) removal process, suggestingreduction of $\mathrm{Fe}$ (III) to $\mathrm{Fe}(\mathrm{II})$ 
occurred in the system, the possible reason was the rapid reaction between Fe(III) and FeBon the surface of the $\mathrm{Fe}_{3} \mathrm{O}_{4}-\mathrm{FeB}$ (Figure 10a). It was hypothesized that $\mathrm{Fe}$ and $\mathrm{B}$ in the $\mathrm{FeB}$ alloy, as well aqueous or adsorbed $\mathrm{Fe}(\mathrm{II})$ generated during the $\mathrm{Cr}(\mathrm{VI})$ removal could contribute to reductive removal of $\mathrm{Cr}(\mathrm{VI})$. To distinguish the role of these reductants on $\mathrm{Cr}(\mathrm{VI})$ removal, we employed 1 , 10-phenanthrolineto complex Fe(II) species. We found the addition of 1, 10-phenanthroline could dramatically suppress $\mathrm{Cr}(\mathrm{VI})$ removal efficiencies of $\mathrm{Fe}_{3} \mathrm{O}_{4}-\mathrm{FeB}$. $\mathrm{Cr}(\mathrm{VI})$ removal decrease from $100 \%$ to $15 \%$ within $15 \mathrm{~min}$, the inhibitory efficiency reached $85.8 \%$ in the presence of 1 , 10-phenanthroline (Figure 10b). This result indicated that Fe(II) species were the maincontributionof $\mathrm{Cr}(\mathrm{VI})$ removal with $\mathrm{Fe}_{3} \mathrm{O}_{4}-\mathrm{FeB}$.

In order to investigateCr(VI) removal mechanism with $\mathrm{Fe}_{3} \mathrm{O}_{4}-\mathrm{FeB}$, XPS spectraof $\mathrm{Fe}_{3} \mathrm{O}_{4}-\mathrm{FeB}$ before and after $\mathrm{Cr}(\mathrm{VI})$ removal $\left(\mathrm{Fe}_{3} \mathrm{O}_{4}-\mathrm{FeB}-\mathrm{Cr}(\mathrm{VI})\right)$ were compared (Figure 11a). The peak in 191.5 eV which was responded to B species disappeared after $\mathrm{Cr}(\mathrm{VI})$ removal (Figure 11b), confirming B element in FeB participated in $\mathrm{Cr}(\mathrm{VI})$ removal process. Additionally, the high resolution XPS of Fe $2 p$ and $\mathrm{Cr} 2 p$ revealed thatFe(II) and $\mathrm{Fe}(\mathrm{III}), \mathrm{Cr}(\mathrm{III})$ and $\mathrm{Cr}(\mathrm{VI})$ coexisted in the $\mathrm{Fe}_{3} \mathrm{O}_{4}-\mathrm{FeB}$ and $\mathrm{Fe}_{3} \mathrm{O}_{4}-\mathrm{FeB}-\mathrm{Cr}(\mathrm{VI})$ samples (Figure 11c, 11d), confirming that both adsorption and reduction co-happened during $\mathrm{Cr}(\mathrm{VI})$ removal process.

Furthermore, we checked electron transfer property by measuring the free corrosion potentials of the commercial $\mathrm{Fe}_{3} \mathrm{O}_{4}$ and $\mathrm{Fe}_{3} \mathrm{O}_{4}-\mathrm{FeBin}$ the presence of $8 \mathrm{mg} \cdot \mathrm{L}^{-1}$ of $\mathrm{Cr}(\mathrm{VI})$ withTafel polarization diagrams. It is known that an electrodeof a more negativefree corrosion potential value possessesa higher electron transfer rate. The $\mathrm{Fe}_{3} \mathrm{O}_{4}-\mathrm{FeB}$ was easier to donate electron than the bare $\mathrm{Fe}_{3} \mathrm{O}_{4}$ as the free corrosion potentials of the $\mathrm{Fe}_{3} \mathrm{O}_{4}-\mathrm{FeB}(-0.76 \mathrm{~V})$ was more negative than that of the $\mathrm{Fe}_{3} \mathrm{O}_{4}(-0.68$ V) (Figure 12a).Because the reduction step is an electron-transfer process, the high electron-transport 
property of $\mathrm{FeB}$ facilitates the reaction in a much faster manner, this was evidenced by the fact that $\mathrm{Fe}_{3} \mathrm{O}_{4}-\mathrm{FeB}$ showed a superior capacity of producing $\mathrm{H}_{2}$ over the bare $\mathrm{Fe}_{3} \mathrm{O}_{4}$ under argon atmosphere (Figure 12b).

3.4 Possible Mechanism of the PromotedCr(VI) Removal. On the basis of the above experiment results and discussion, we proposed a possible mechanism for the promotedCr(VI) removal with $\mathrm{Fe}_{3} \mathrm{O}_{4}-\mathrm{FeB}$ (Scheme 1).As soon as $\mathrm{Fe}_{3} \mathrm{O}_{4}-\mathrm{FeB}$ was exposed to $\mathrm{Cr}(\mathrm{VI})$ solution at neutral $\mathrm{pH}, \mathrm{Cr}(\mathrm{VI})$ in form of $\mathrm{Cr}_{2} \mathrm{O}_{7}{ }^{2-}$ would adsorb on the positively charged surface ofFe $\mathrm{O}_{4}-\mathrm{FeBvia}$ electrostatic interaction.Fe and $\mathrm{B}$ of the $\mathrm{FeB}$ alloy could reduce $\mathrm{Cr}(\mathrm{VI})$ adsorbed on the $\mathrm{Fe}_{3} \mathrm{O}_{4}-\mathrm{FeB}$ surfaceinto $\mathrm{Cr}(\mathrm{III})$, simultaneously $\mathrm{Fe}(\mathrm{III})$ and $\mathrm{BO}_{2}{ }^{-}$species were generated (Eqs. 7, 8), as evidenced by the XPS analysis. Both $\mathrm{Fe}$ and $\mathrm{B}$ in the FeBcould reduce the generated Fe(III) to formFe(II) species (Eqs. 9, 10), these generated $\mathrm{Fe}(\mathrm{II})$ would also initiate $\mathrm{Cr}(\mathrm{VI})$ reduction (Eq. 11), this was confirmed by Tafel polarization analysis and aqueous boron species measurement result. Here boron elements containing many free electrons could accelerate electron transfer from Fe to the adsorbed $\mathrm{Cr}(\mathrm{VI})$, as well reduce $\mathrm{Fe}(\mathrm{III})$ to $\mathrm{Fe}(\mathrm{II})$ and thus promote $\mathrm{Fe}(\mathrm{III}) / \mathrm{Fe}(\mathrm{II})$ cycles, resulting in promotion of $\mathrm{Cr}(\mathrm{VI})$ removal efficiency of $\mathrm{Fe}_{3} \mathrm{O}_{4}$-FeB.Subsequently, $\mathrm{Cr}$ (III) species referred to form polymeric $\mathrm{Cr}(\mathrm{III})$ hydroxidesbecause of its much less inflexibility. Finally, $\mathrm{Cr}(\mathrm{VI})$ could bound into these polymeric $\mathrm{Cr}(\mathrm{III})$ hydroxides through $\mathrm{Cr}(\mathrm{III})-\mathrm{O}-\mathrm{Cr}(\mathrm{VI})$ linkages to produce $\mathrm{Fe}(\mathrm{III}) / \mathrm{Cr}(\mathrm{III}) / \mathrm{Cr}(\mathrm{VI})$ composite oxide layer on the surface ofFe ${ }_{3} \mathrm{O}_{4}-\mathrm{FeB}$ (Eq.12) [29].B element may diffuse automatically from the bulk to the surface during the $\mathrm{Cr}(\mathrm{VI})$ removal, such diffusion would continue until all the bulk boron was consumed [30].

$$
\begin{aligned}
& \mathrm{Cr}_{2} \mathrm{O}_{7}{ }^{2-}+2 \mathrm{Fe}+8 \mathrm{H}^{+} \rightarrow 2 \mathrm{Fe}^{3+}+2 \mathrm{Cr}(\mathrm{OH})_{3}+\mathrm{H}_{2} \mathrm{O}(7) \\
& \mathrm{Cr}_{2} \mathrm{O}_{7}{ }^{2-}+2 \mathrm{~B}+3 \mathrm{H}_{2} \mathrm{O} \rightarrow 2 \mathrm{BO}_{2}^{-}+2 \mathrm{Cr}(\mathrm{OH})_{3}(8)
\end{aligned}
$$




$$
\begin{aligned}
& 3 \mathrm{Fe}^{3+}+\mathrm{B}+2 \mathrm{H}_{2} \mathrm{O} \rightarrow 2 \mathrm{Fe}^{2+}+\mathrm{BO}_{2}{ }^{-}+4 \mathrm{H}^{+}(9) \\
& 2 \mathrm{Fe}^{3+}+\mathrm{Fe} \rightarrow 3 \mathrm{Fe}^{2+}(10) \\
& \mathrm{Cr}_{2} \mathrm{O}_{7}{ }^{2-}+6 \mathrm{Fe}^{2+}+8 \mathrm{H}^{+} \rightarrow 6 \mathrm{Fe}^{3+}+\mathrm{Cr}_{2} \mathrm{O}_{3}+4 \mathrm{H}_{2} \mathrm{O} \\
& 2 \equiv \mathrm{Cr}(\mathrm{OH})_{3 \text { (suf) }}+\mathrm{Cr}_{2} \mathrm{O}_{7}{ }_{(\text {sol })} \rightarrow \equiv \mathrm{Cr}(\mathrm{OH})_{3}-\mathrm{Cr}_{2} \mathrm{O}_{7}{ }^{2-}-\mathrm{Cr}(\mathrm{OH})_{3} \equiv{ }_{(\text {suf })}(12)
\end{aligned}
$$

3.5 Implications for Cr(VI) Removal in Aquatic Systems. Magnetic properties of the commercial $\mathrm{Fe}_{3} \mathrm{O}_{4}$, fresh prepared $\mathrm{Fe}_{3} \mathrm{O}_{4}-\mathrm{FeB}$, and used $\mathrm{Fe}_{3} \mathrm{O}_{4}-\mathrm{FeB}-\mathrm{Cr}(\mathrm{VI})$ were measured at $300 \mathrm{~K}$ (Figure 13a). All the samples showed a ferromagnetic performance. The fresh prepared $\mathrm{Fe}_{3} \mathrm{O}_{4}-\mathrm{FeB}$ exhibited a saturation magnetization value of $84.48 \mathrm{emu} \mathrm{g}^{-1}$. Owing to the strong ferromagnetic behavior of $\mathrm{Fe}_{3} \mathrm{O}_{4}-\mathrm{FeB}$, the adsorbed $\mathrm{Cr}(\mathrm{VI})$ contaminant can be easily separated from aqueous solution by means of an external magnet, which was much simpler than using centrifugation of non-magnetic adsorbents (Figure 13b). We found that $\mathrm{Cr}(\mathrm{VI})$ removal efficiency decreased during the re-cycled $\mathrm{Cr}(\mathrm{VI})$ removal processwith $\mathrm{Fe}_{3} \mathrm{O}_{4}-\mathrm{FeB}$ (Figure 13c), because $\mathrm{Cr}(\mathrm{VI})$ was mainly reductively removed by electrons donated from Fe and B as soon as adsorbed, followed by an in-situ formation of $\mathrm{Cr}(\mathrm{III}) / \mathrm{Fe}(\mathrm{III})$ oxyhydroxides subsurface layer and simultaneous adsorption of $\mathrm{Cr}(\mathrm{VI})$ on this subsurface to generate $\mathrm{Cr}(\mathrm{III}) / \mathrm{Fe}(\mathrm{III}) / \mathrm{Cr}(\mathrm{VI})$ oxyhydroxides surface. The incrassated $\mathrm{Cr}(\mathrm{III}) / \mathrm{Fe}(\mathrm{III}) / \mathrm{Cr}(\mathrm{VI})$ oxyhydroxides shell could inhibit the electron transfer, leading to the decrease of $\mathrm{Cr}(\mathrm{VI})$ removal [29]. The used $\mathrm{Fe}_{3} \mathrm{O}_{4}-\mathrm{FeB}$ could be regenerated after the re-treatment with $\mathrm{NaBH}_{4}$ (Figure 13c), suggestingits potential of real application in $\mathrm{Cr}(\mathrm{VI})$ wastewater treatment.

\section{Conclusions}

In summary, $\mathrm{Fe}_{3} \mathrm{O}_{4}-\mathrm{FeB}$ has beenfacilely synthesized by interfacialreduction of commercialFe $\mathrm{O}_{4}$ nanoparticles with $\mathrm{NaBH}_{4}$. The $\mathrm{Fe}_{3} \mathrm{O}_{4}-\mathrm{FeB}$ displayed a promotedCr(VI)removal 
efficiency compared withthe bare $\mathrm{Fe}_{3} \mathrm{O}_{4}$ counterpart, the interfacial reduced $\mathrm{Fe}_{3} \mathrm{O}_{4}-\mathrm{H}_{2}$ and/or $\mathrm{Fe}_{3} \mathrm{O}_{4}-\mathrm{N}_{2} \mathrm{H}_{4} \cdot \mathrm{H}_{2} \mathrm{O}$. The high $\mathrm{Cr}(\mathrm{VI})$ removal efficiency of the $\mathrm{Fe}_{3} \mathrm{O}_{4}-\mathrm{FeB}$ was highly depended on the amorphous FeB alloy, where the boron elements containing many free electrons could accelerate the electrons transfer from Feto the adsorbed $\mathrm{Cr}(\mathrm{VI})$, as well reduce $\mathrm{Fe}(\mathrm{III})$ to $\mathrm{Fe}(\mathrm{II})$ and thus promote the $\mathrm{Fe}(\mathrm{III}) / \mathrm{Fe}(\mathrm{II})$ cycles. The efficient $\mathrm{Cr}(\mathrm{VI})$ removal under a wide range of $\mathrm{pH}$ values and its easy magnetic separationmake the low-cost $\mathrm{Fe}_{3} \mathrm{O}_{4}-\mathrm{FeB}$ to be a potential material for $\mathrm{Cr}(\mathrm{VI})$ contaminated water treatment.

Acknowledgements. This work was supported by National Science Foundation of China (Grants 21173093, 21477044), Self-determined research funds of CCNU from the Colleges' Basic Research and Operation of MOE (CCNU14KFY002), and Program for Distinguished Young Scientist of Hubei Province (2013CFA030).

\section{Reference}

[1] L.Dupont, E.Guillon, Removal of hexavalent chromium with a lignocellulosic substrate extracted from wheat bran.Environ. Sci. Technol.37(2003) 4235-4241.

[2] R. S. Cutting, V. S. Coker, N. D. Telling, R. L. Kimber, C. I. Pearce, B. L. Ellis, R. S. Lawson, V.Gerrit, R. A. D. Pattrick, D. J. Vaughan, E. Arenholz, J. R. Lloyd, Optimizing Cr(VI) and Tc(VII) remediation through nanoscale biomineral engineering.Environ. Sci. Technol. 44 (2010) 2577-2584. [3] X.Guo, G. T.Fei, H. Su, L. D.Zhang, High performance and reproducible polyaniline nanowire/tubes for removal of $\mathrm{Cr}(\mathrm{VI})$ from aqueous solution. J. Phys. Chem. C.115 (2011)1608-1613. 
[4] Z. H. Ai, Y. Cheng, L. Z. Zhang, J. R. Qiu, Efficient removal of Cr(VI) from aqueous solution with $\mathrm{Fe} @ \mathrm{Fe}_{2} \mathrm{O}_{3}$ core-shell nanowires.Environ. Sci. Technol. 42 (2008) 6955-6960.

[5] X. S. Lv, J. Xu, G. M. Jiang, J. Tang, X. H. Xu, Highly active nanoscale zero-valent iron (nZVI)- $\mathrm{Fe}_{3} \mathrm{O}_{4}$ nanocomposites for the removal of chromium(VI) from aqueous solutions. J. Colloid Interface Sci. 369 (2012) 460-469.

[6] Z. H. Wang, W. H. Ma, C. C. Chen, J. C. Zhao, Photochemical coupling reactions between $\mathrm{Fe}(\mathrm{III}) / \mathrm{Fe}(\mathrm{II}), \mathrm{Cr}(\mathrm{VI}) / \mathrm{Cr}(\mathrm{III})$, and polycarboxylates: Inhibitory effect of $\mathrm{Cr}$ species.Environ. Sci. Technol. 42 (2008) 7260-7266.

[7] Y. C. Sharma, V. Srivastava, Comparative studies of removal of Cr(VI) and Ni(II) from aqueous solutions by magnetic nanoparticles.J. Chem. Eng. Data.56 (2011) 819-825.

[8] J.Hu, I. M. C. Lo, G. Chen, Removal of Cr(VI) by magnetite nanoparticle.Water Sci. Technol.50 (2004), 139-146.

[9] M. Bhaumik, A. Maity, C. C. Srinivasu, M. S. Onyango, Enhanced removal of Cr(VI) from aqueous solution using polypyrrole/ $\mathrm{Fe}_{3} \mathrm{O}_{4}$ magnetic nanocomposite. J. Hazard. Mater. 190 (2011) 381-390.

[10] Y. G. Zhao, H. Y. Shen, S. D. Pan, M. Q. Hu, Synthesis, characterization and properties of ethylenediamine-functionalized $\mathrm{Fe}_{3} \mathrm{O}_{4}$ magnetic polymers for removal of $\mathrm{Cr}(\mathrm{VI})$ in wastewater. $\mathrm{J}$. Hazard. Mater. 182 (2010) 295-302.

[11] W. J. Jiang, Q. Cai, W. Xi, M. W. Yang, Y. Cai, D. D. Dionysiou, K. E. O`Shea, Cr(VI) adsorption and reduction by humic acid coated on magnetite. Environ. Sci. Technol. 48 (2014) 8078-8085.

[12] H. Wang, X. Yuan, Y. Wu, X. Chen, L. Leng, H. Wang, H. Li, G. Zeng, Facile synthesis of 
polypyrrole decorated reduced graphene oxide- $\mathrm{Fe}_{3} \mathrm{O}_{4}$ magnetic composites and its application for the Cr(VI) removal.Chem. Eng. J. 26 (2015) 2597-2606.

[13] X. Lv, G. Jiang, X. Xue, D. Wu, T. Sheng, C. Sun, X. Xu, J. $\mathrm{Fe}^{0}-\mathrm{Fe}_{3} \mathrm{O}_{4}$ nanocomposites embedded polyvinyl alcohol/sodiumalginate beads for chromium(VI) removal. Hazard. Mater. 262 (2013) 748-758.

[14] H. Wu, Z. Ai, L. Zhang, Anoxic and oxic removal of humic acids with $\mathrm{Fe}_{0} @ \mathrm{Fe}_{2} \mathrm{O}_{3}$ core-shell nanowires: A comparative study. Water Res. 52 (2014) 92-100.

[15]V. P. Sarai, L. H. Ivonne, M. M. Verónica, Boron-doped diamond electrode performance in Cr(VI) reduction using synthetic and plating wastewater. Sep. Sci. Technol. 48 (2013) 427-433.

[16] American Society of Testing Materials (ASTM). Am. Soc. Test. Mater. 1990, D1987-86.

[17] American Public Health Association (APHA), Standard Methods for the Examination of Water and Wastewater, 17th ed., 1985.

[18] S. Shi, Y. W. Fan, Y. M. Huang, Facile low temperature hydrothermal synthesis of magnetic mesoporous carbon nanocomposite for adsorption removal of ciprofloxacin antibiotics. Ind. Chem. Res.52(2013) 2604-2612.

[19] G. Liu, Q. Deng, H. M. Wang, S. H. Kang, Y. Yang, D. H.L. Ng, W. P. Cai, G. Z. Wang, Synthesis and characterization of nanostructured $\mathrm{Fe}_{3} \mathrm{O}_{4}$ micron-spheres and their application in removing toxic Cr ions from polluted water. Chem. Eur. J.18 (2012)13418-13426.

[20] L. Ling, W. X. Zhang, Reactions of nanoscale zero-valent iron with Ni(II): Three-dimensional tomography of the "hollow out" effect in a single nanoparticle. Environ. Sci. Technol. Lett.1 (2014) 209-213.

[21] P. Fulmer, R. M. Manivel, A. Manthiram, Chemical synthesis, processing, and characterization 
of nanostructured Fe-B for the magnetically assisted chemical separation of hazardous waste.Chem. Mater. 13 (2001) 2160-2168.

[22] S. J. Cho, A. M. Shahin, G. J. Long, J. E. Davies, K. Liu, F. Grandjean, S. M. Kauzlarich, Magnetic and Mössbauer spectral study of core/shell structured Fe/Au nanoparticles. Chem. Mater. 18 (2006) 960-967.

[23] N. Duxin, O. Stephan, C. Petit,P. Bonville, C. Colliex, M. P. Pileni, Pure $\alpha-F e$ coated by an $\mathrm{Fe}_{1-\mathrm{x}} \mathrm{B}_{\mathrm{x}}$ alloy. Chem. Mater. 9 (1997) 2096-2100.

[24] B. Rajesh, N. Sasirekha, Y. W. Chen, S. P. Lee, Effect of synthesis parameters on the characteristics of Fe-B nanoalloys for dehydrogenation of ethanol.Ind. Eng. Chem. Res. 46 (2007) 2034-2041.

[25] J. L. Wang, Y. L. Gu, Z. L. Li, W. M. Wang, Z. Y. Fu, Growth and optical properties of explosion phase boron nitride octahedron crystals.Cryst. Growth Des. 13 (2013) 599-605.

[26] Y. J. Song, S. X. Ji, Y. J. Song, R. S. Li, J. Ding, X. M. Shen, R. M. Wang, R. W. Xu, X. Y. Gu, In situ redox microfluidic synthesis of core-shell nanoparticles and their long-term stability.J. Phys. Chem. C 117 (2013) 17274-17284.

[27] W. L. Dai, H. X. Li, Y. Cao, M. H. Qiao, K. N. Fan, J. F. Deng, Evidence for the antioxidation effect of boron on the ultrafine amorphous Ni-B alloy catalyst. Langmuir. 18 (2002) 9605-9608.

[28] A. W. Laubengayer, D. T. Hurd, A. E. Newkirk,Boron. I. Hoard, Preparation and properties of pure crystalline boron. J. Am. Chem. Soc. 65 (1943) 1924-1931.

[29] Y. Mu, Z. Ai, L. Zhang, F. Song, Insight into core-shell dependent anoxic Cr(VI) removal with $\mathrm{Fe} @ \mathrm{Fe}_{2} \mathrm{O}_{3}$ nanowires: Indispensable role of surface bound $\mathrm{Fe}(\mathrm{II})$. ACS appl. Mater. Interfaces. 7 (2015) 1997-2003. 
[30] K. F. Huo, Z. Hu, J. J. Fu, H. Xu, X. Z. Wang, Y. Chen, Microstructure and growth model of periodic spindle-unit $\mathrm{BN}$ nanotubes by nitriding Fe-B nanoparticles with nitrogen/ammonia mixture. J. Phys. Chem. B. 107 (2003) 11316-11320.

\section{Figure Caption}

Figure 1. SEM images of the commercial $\mathrm{Fe}_{3} \mathrm{O}_{4}$ (a) and powders treated with $\mathrm{NaBH}_{4}$ (b); XRD patterns (c) andN $\mathrm{N}_{2}$ adsorption and desorption isotherms (d) of $\mathrm{Fe}_{3} \mathrm{O}_{4}$ and powders treated with $\mathrm{NaBH}_{4}$.

Figure 2. TEM and HRTEM images of the commercial $\mathrm{Fe}_{3} \mathrm{O}_{4}(\mathrm{a}, \mathrm{b}, \mathrm{c})$, and the $\mathrm{NaBH}_{4}$ treated $\mathrm{Fe}_{3} \mathrm{O}_{4}$ $(d, e, f)$.

Figure 3. EFTEM images of the commercialFe $\mathrm{O}_{4}$ (a) andthe treated $\mathrm{Fe}_{3} \mathrm{O}_{4}$ (e). EFTEM element mapping images of theFe $\mathrm{O}_{4}\left(\mathrm{~b}, \mathrm{c}\right.$, and d) and the treated $\mathrm{Fe}_{3} \mathrm{O}_{4}$ (f, g, and h).

Figure 4. Mössbauer spectra of the $\mathrm{Fe}_{3} \mathrm{O}_{4}$ before and after $\mathrm{NaBH}_{4}$ treatment.

Figure 5. XPS spectra of the $\mathrm{Fe}_{3} \mathrm{O}_{4}$ before and after $\mathrm{NaBH}_{4}$ treatment, (a) XPS survey; (b) high resolution of $\mathrm{Fe} 2 \mathrm{p}$; (c) high resolution of $\mathrm{B}$ 1s.

Figure 6. Time profile of $\mathrm{Cr}(\mathrm{VI})$ removal withFe $\mathrm{O}_{4}$ and $\mathrm{Fe}_{3} \mathrm{O}_{4}-\mathrm{FeB}$ with different treatment time (a), and concentrations (c); plots of $-\ln \left(\mathrm{C} / \mathrm{C}_{0}\right)$ versus time withsamples with different treatment time (b), and concentrations (d).

Figure 7. Time profiles of the initial $\mathrm{pH}$ values on $\mathrm{Cr}(\mathrm{VI})$ removal with $\mathrm{Fe}_{3} \mathrm{O}_{4}-\mathrm{FeB}\left(\mathrm{Fe}_{3} \mathrm{O}_{4}-\mathrm{FeB} 0.8\right.$ $\left.\mathrm{g} \cdot \mathrm{L}^{-1}, \mathrm{Cr}(\mathrm{VI}) 8 \mathrm{mg} \cdot \mathrm{L}^{-1}\right)(\mathrm{a})$, removal kinetics of $\mathrm{Cr}(\mathrm{VI})$ removal at different initial $\mathrm{pH}$ values (b), time profiles of the initial $\mathrm{Cr}(\mathrm{VI})$ concentrations $\left(4-32 \mathrm{mg} \cdot \mathrm{L}^{-1}\right)$ on $\mathrm{Cr}(\mathrm{VI})$ removal (c), and pseudo-second-order kinetic model, $\mathrm{Fe}_{3} \mathrm{O}_{4}-\mathrm{FeB}$ was $0.8 \mathrm{~g} \cdot \mathrm{L}^{-1}$; initial concentrations of $\mathrm{Cr}(\mathrm{VI})$ were 4 
to $32 \mathrm{mg} \cdot \mathrm{L}^{-1}(\mathrm{~d})$.

Figure 8.SEM images of $\mathrm{Fe}_{3} \mathrm{O}_{4}-\mathrm{H}_{2}(\mathrm{a})$, and $\mathrm{Fe}_{3} \mathrm{O}_{4}-\mathrm{N}_{2} \mathrm{H}_{4} \cdot \mathrm{H}_{2} \mathrm{O}$ (b);XRD patterns (c), and XPS spectra (d) of $\mathrm{Fe}_{3} \mathrm{O}_{4}-\mathrm{N}_{2} \mathrm{H}_{4} \cdot \mathrm{H}_{2} \mathrm{O}$ and $\mathrm{Fe}_{3} \mathrm{O}_{4}-\mathrm{H}_{2}$.

Figure 9. Time profile of $\mathrm{Cr}(\mathrm{VI})$ removal with $\mathrm{Fe}_{3} \mathrm{O}_{4}, \mathrm{Fe}_{3} \mathrm{O}_{4}-\mathrm{FeB}, \mathrm{Fe}_{3} \mathrm{O}_{4}-\mathrm{N}_{2} \mathrm{H}_{4} \cdot \mathrm{H}_{2} \mathrm{O}$, and $\mathrm{Fe}_{3} \mathrm{O}_{4}-\mathrm{H}_{2}$.

Figure 10. (a) Time profile of concentrations of $\mathrm{B}, \mathrm{Fe}(\mathrm{II})$, and $\mathrm{Fe}(\mathrm{III})$ in solution; (b) time profile of $\mathrm{Cr}(\mathrm{VI})$ removal with $\mathrm{Fe}_{3} \mathrm{O}_{4}-\mathrm{FeB}$ in the absence or presence of 1,10-phenanthroline.

Figure 11. XPS spectra of $\mathrm{Fe}_{3} \mathrm{O}_{4}$-FeB before and after $\mathrm{Cr}(\mathrm{VI})$ removal, (a) XPS survey;(b) high resolution of B 1s; (c) high resolution of Fe 2p; and (d) high resolution of $\mathrm{Cr} 2 \mathrm{p}$.

Figure 12. (a) Tafel plots; (b) temporal concentration change of hydrogen evolution of $\mathrm{Fe}_{3} \mathrm{O}_{4}$ and $\mathrm{Fe}_{3} \mathrm{O}_{4}-\mathrm{FeB}$ in the system.

Figure 13. (a) Magnetic hysteresis loop measured at $300 \mathrm{~K}$, the enlarged magnetization curve between -800 and 800 Oe (inset); (b) photographs of magnetic separation: (I) $8 \mathrm{mg} \mathrm{L}^{-1} \mathrm{Cr}$ (VI); (II) a mixture of $\mathrm{Fe}_{3} \mathrm{O}_{4}-\mathrm{FeB}$ with $8 \mathrm{mg} \mathrm{L}{ }^{-1} \mathrm{Cr}(\mathrm{VI})$ solution; (III) magnetic separation of $\mathrm{Fe}_{3} \mathrm{O}_{4}-\mathrm{FeB}$ from the solution;(c) Reusability of $\mathrm{Fe}_{3} \mathrm{O}_{4}-\mathrm{FeB}$ : left, $\mathrm{Fe}_{3} \mathrm{O}_{4}-\mathrm{FeB}$ recycled to the next removal without any treating; (b) the recycled solid was retreated by $\mathrm{NaBH}_{4}$ to the next removal.

Scheme 1. Schematic Cr(VI) removal mechanism with $\mathrm{Fe}_{3} \mathrm{O}_{4}-\mathrm{FeB}$.

Table 1. Mössbauer spectrahyperfine parameters.

Table 2. Ratio of $\mathrm{Fe}^{\mathrm{II}} / \mathrm{Fe}_{\text {total }}$ and $\mathrm{Fe}^{\mathrm{III}} / \mathrm{Fe}_{\text {total }}$ in $\mathrm{Fe} 2 \mathrm{p}$ core level spectra, and ratio of $\mathrm{B}$ in oxides to total $\left(\mathrm{B} / \mathrm{B}_{\text {total }}\right)$ of the $\mathrm{Fe}_{3} \mathrm{O}_{4}, \mathrm{Fe}_{3} \mathrm{O}_{4}-\mathrm{FeB}, \mathrm{Fe}_{3} \mathrm{O}_{4}-\mathrm{H}_{2}$, and $\mathrm{Fe}_{3} \mathrm{O}_{4}-\mathrm{N}_{2} \mathrm{H}_{4} \bullet \mathrm{H}_{2} \mathrm{O}$ samples.

Table 3. Theoretical and calculatedq $\mathrm{q}_{\mathrm{e}}$ values, $\mathrm{k}_{2}$, and $\mathrm{R}^{2}$.

Table 4. $\mathrm{Cr}(\mathrm{VI})$ removal capacities of various adsorbents.

Table 5. Langmuir and Freundlich isotherm parameters for $\mathrm{Cr}(\mathrm{VI})$ removal by $\mathrm{Fe}_{3} \mathrm{O}_{4}-\mathrm{FeB}$. 


\section{Figure Caption}
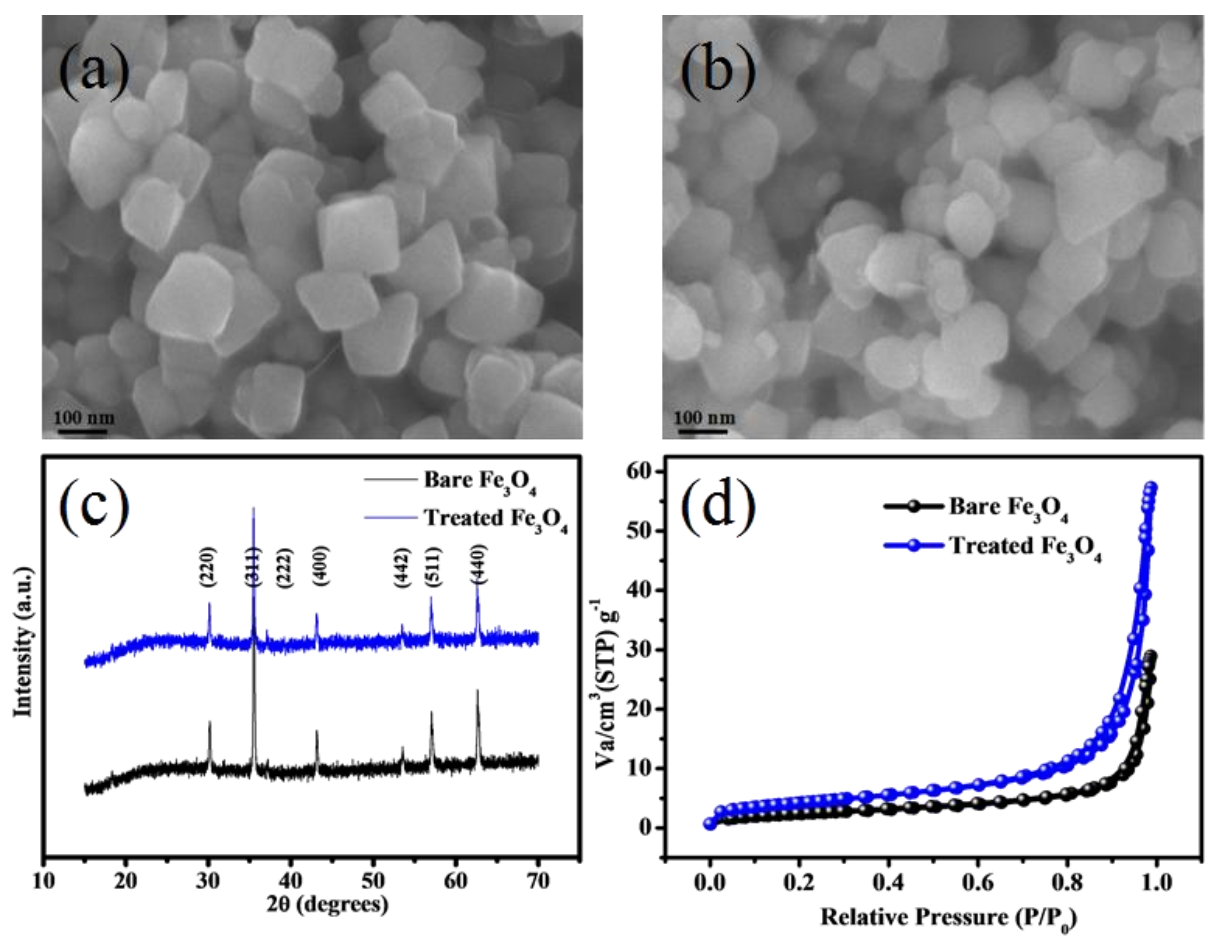

Figure 1. SEM images of the commercial $\mathrm{Fe}_{3} \mathrm{O}_{4}$ (a) and powders treated with $\mathrm{NaBH}_{4}$ (b); XRD patterns (c) andN $\mathrm{N}_{2}$ adsorption and desorption isotherms (d) of $\mathrm{Fe}_{3} \mathrm{O}_{4}$ and powders treated with $\mathrm{NaBH}_{4}$. 


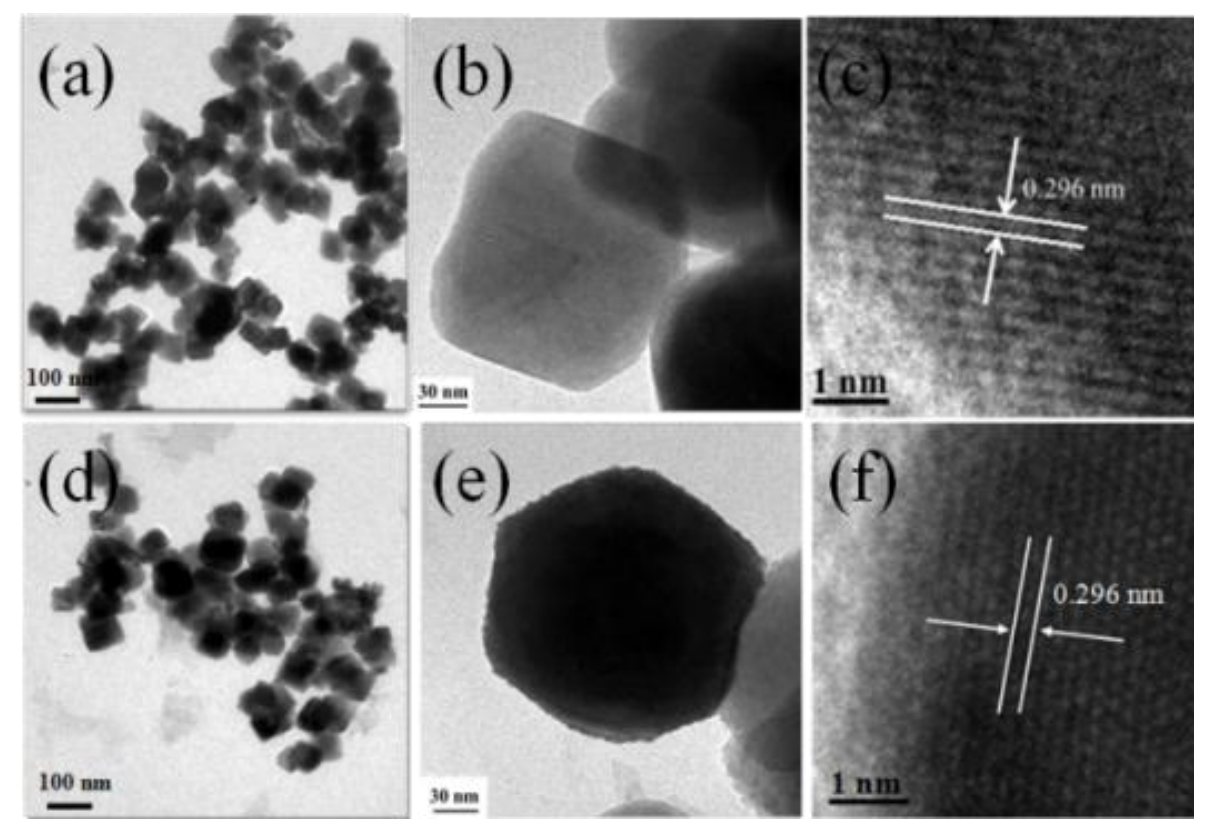

Figure 2. TEM and HRTEM images of the commercial $\mathrm{Fe}_{3} \mathrm{O}_{4}(\mathrm{a}, \mathrm{b}, \mathrm{c})$, and the $\mathrm{NaBH}_{4}$ treated $\mathrm{Fe}_{3} \mathrm{O}_{4}$ $(d, e, f)$.
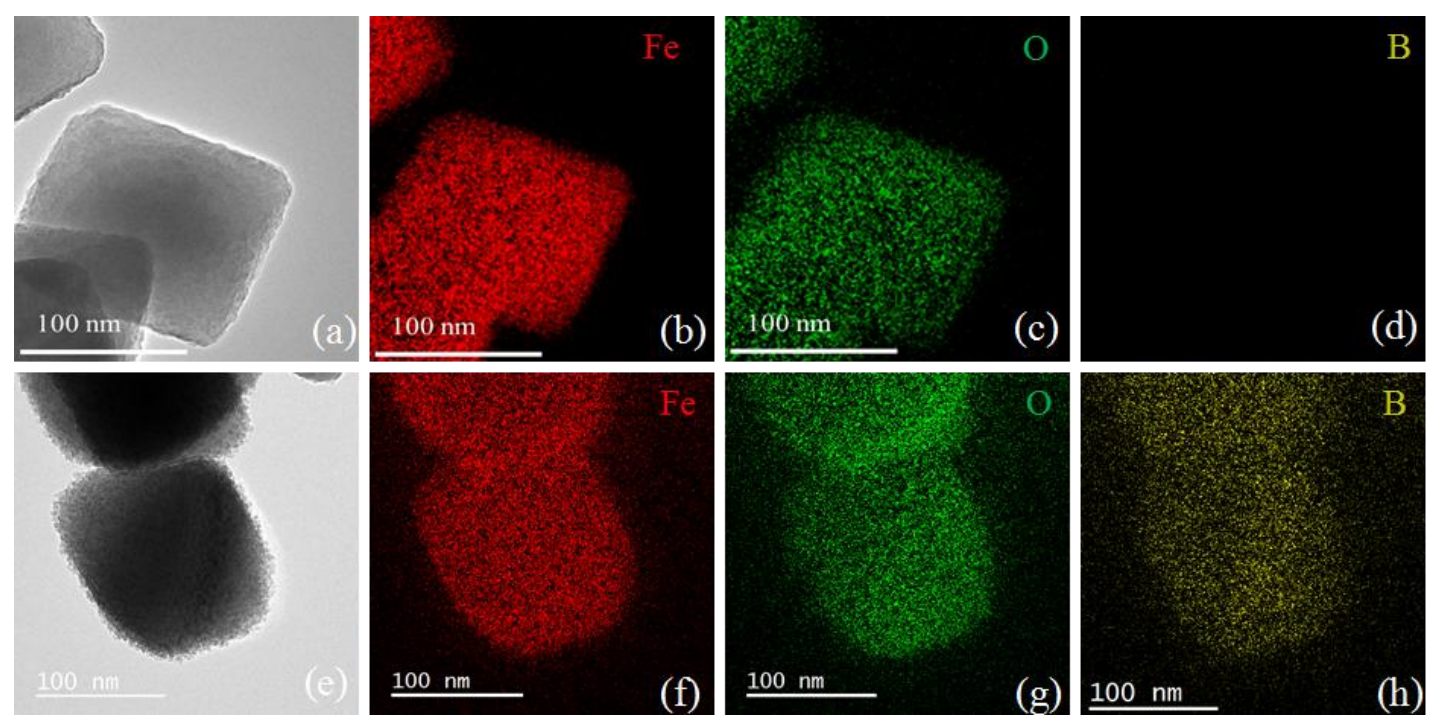

Figure 3. EFTEM images of the commercialFe $\mathrm{O}_{4}$ (a) andthe treated $\mathrm{Fe}_{3} \mathrm{O}_{4}$ (e). EFTEM element mapping images of theFe $\mathrm{O}_{4}\left(\mathrm{~b}, \mathrm{c}\right.$, and d) and the treated $\mathrm{Fe}_{3} \mathrm{O}_{4}$ (f, g, and h). 


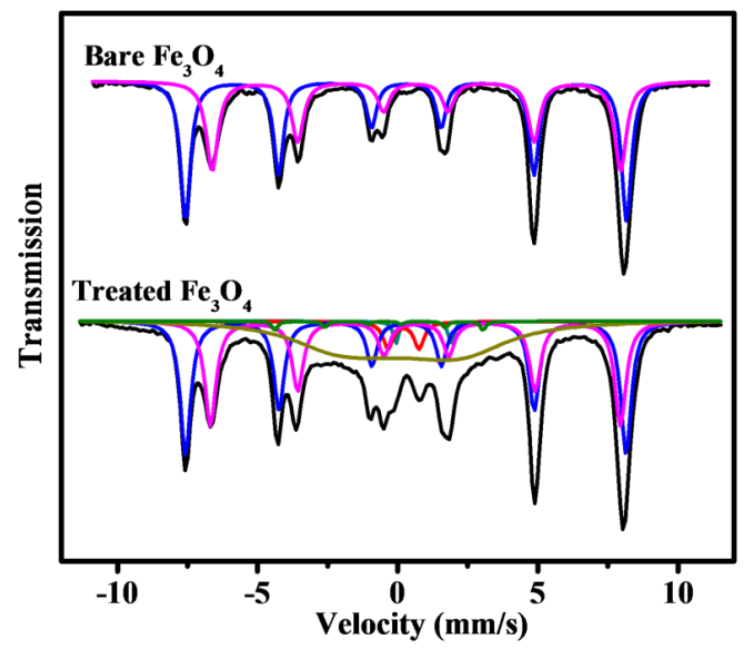

Figure 4. Mössbauer spectra of the $\mathrm{Fe}_{3} \mathrm{O}_{4}$ before and after $\mathrm{NaBH}_{4}$ treatment.
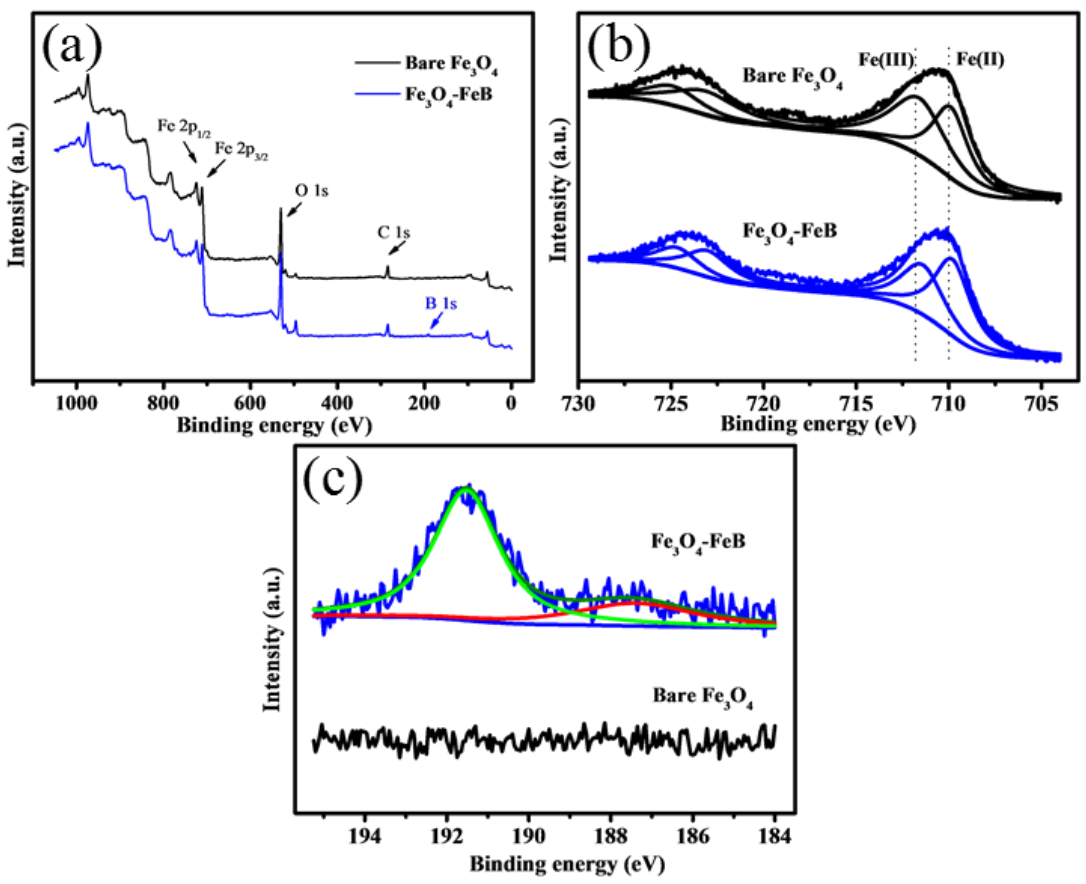

Figure 5. XPS spectra of the $\mathrm{Fe}_{3} \mathrm{O}_{4}$ before and after $\mathrm{NaBH}_{4}$ treatment, (a) XPS survey; (b) high resolution of Fe 2p; (c) high resolution of B 1s. 

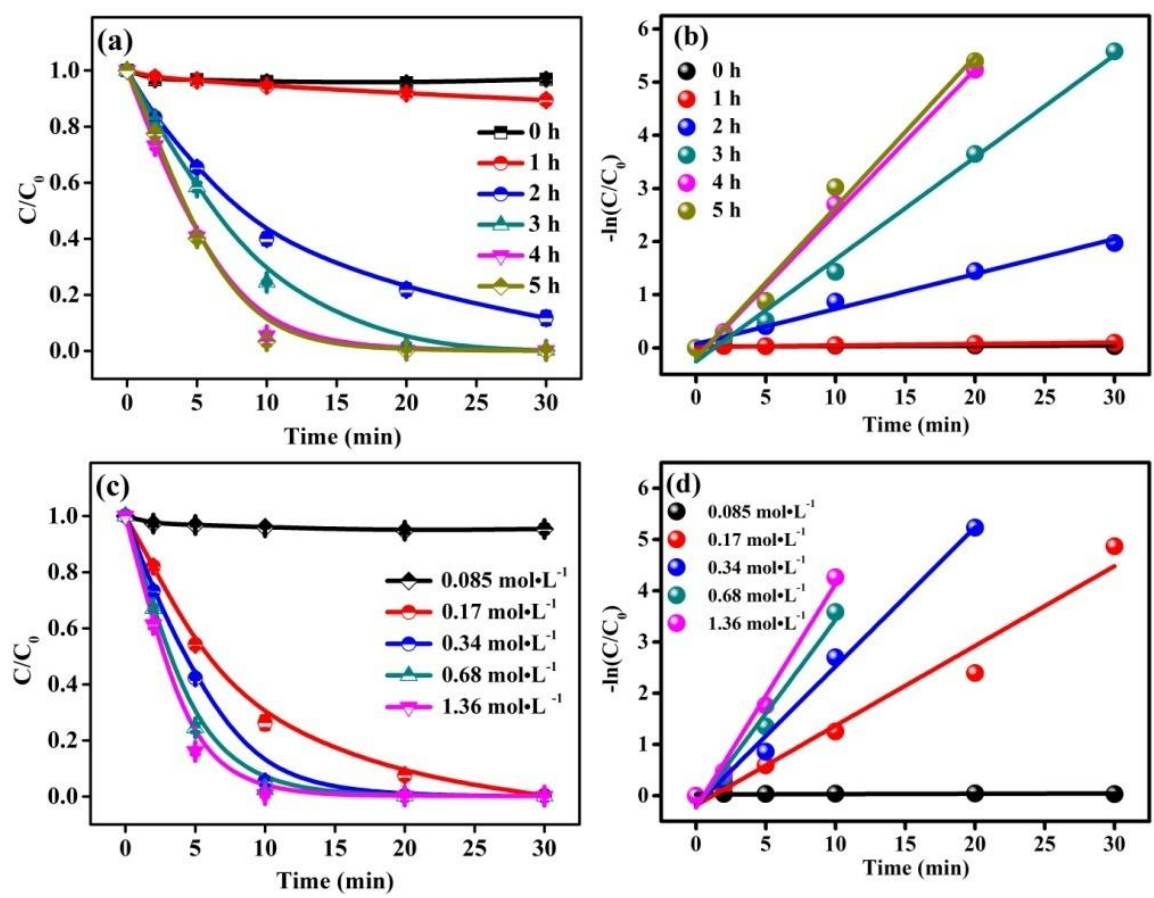

Figure 6. Time profile of $\mathrm{Cr}(\mathrm{VI})$ removal withFe $\mathrm{O}_{4}$ and $\mathrm{Fe}_{3} \mathrm{O}_{4}-\mathrm{FeB}$ with different treatment time (a), and concentrations $(\mathrm{c})$; plots of $-\ln \left(\mathrm{C} / \mathrm{C}_{0}\right)$ versus time withsamples with different treatment time(b), and concentrations $(\mathrm{d})$. 

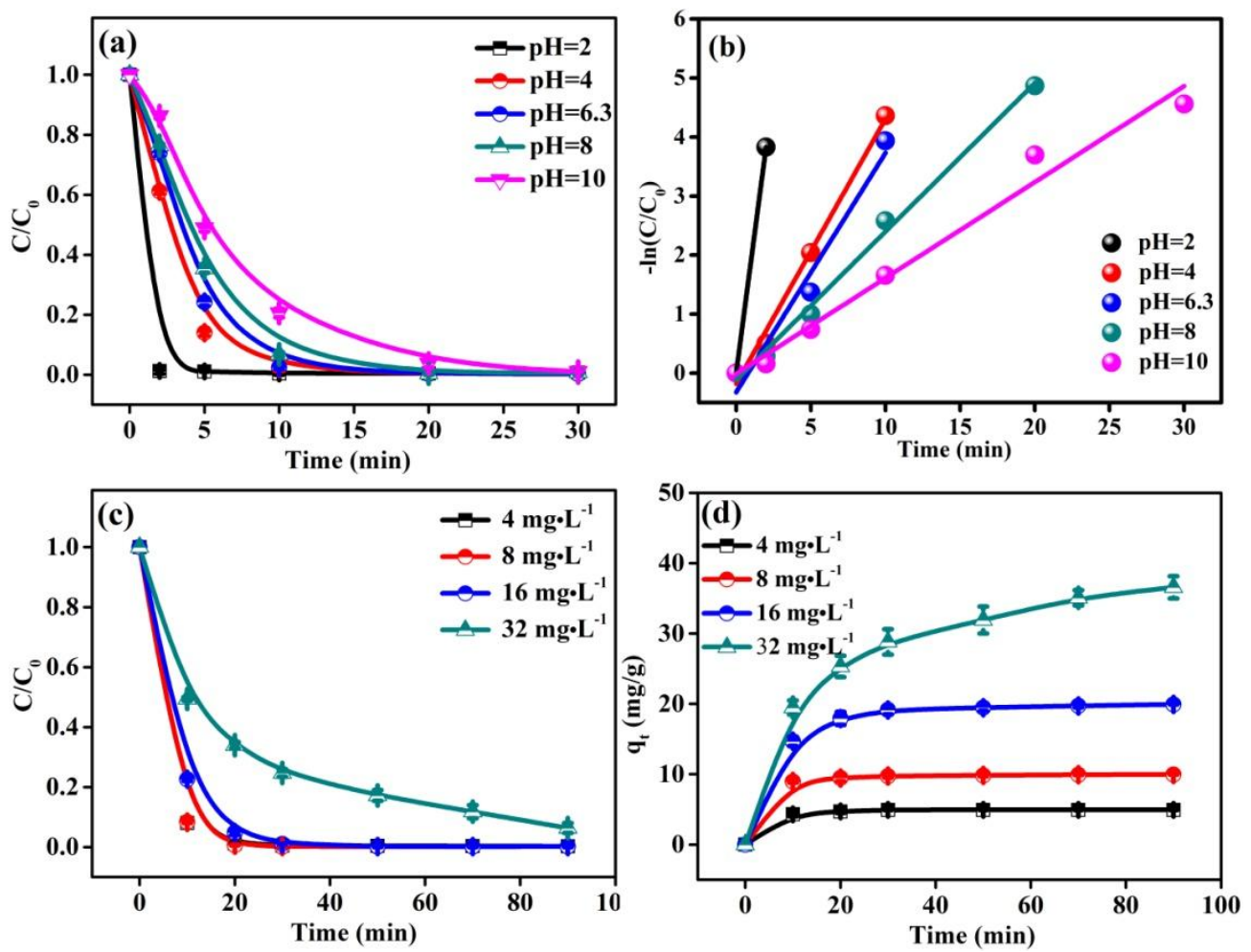

Figure 7. Time profiles of the initial $\mathrm{pH}$ values on $\mathrm{Cr}(\mathrm{VI})$ removal with $\mathrm{Fe}_{3} \mathrm{O}_{4}-\mathrm{FeB}\left(\mathrm{Fe}_{3} \mathrm{O}_{4}-\mathrm{FeB} 0.8\right.$ $\left.\mathrm{g} \cdot \mathrm{L}^{-1}, \mathrm{Cr}(\mathrm{VI}) 8 \mathrm{mg} \bullet \mathrm{L}^{-1}\right)(\mathrm{a})$, removal kinetics of $\mathrm{Cr}(\mathrm{VI})$ removal at different initial $\mathrm{pH}$ values (b), time profiles of the initial $\mathrm{Cr}(\mathrm{VI})$ concentrations $\left(4-32 \mathrm{mg} \cdot \mathrm{L}^{-1}\right)$ on $\mathrm{Cr}(\mathrm{VI})$ removal (c), and pseudo-second-order kinetic model, $\mathrm{Fe}_{3} \mathrm{O}_{4}-\mathrm{FeB}$ was $0.8 \mathrm{~g} \cdot \mathrm{L}^{-1}$; initial concentrations of $\mathrm{Cr}(\mathrm{VI})$ were 4 to $32 \mathrm{mg} \cdot \mathrm{L}^{-1}(\mathrm{~d})$. 

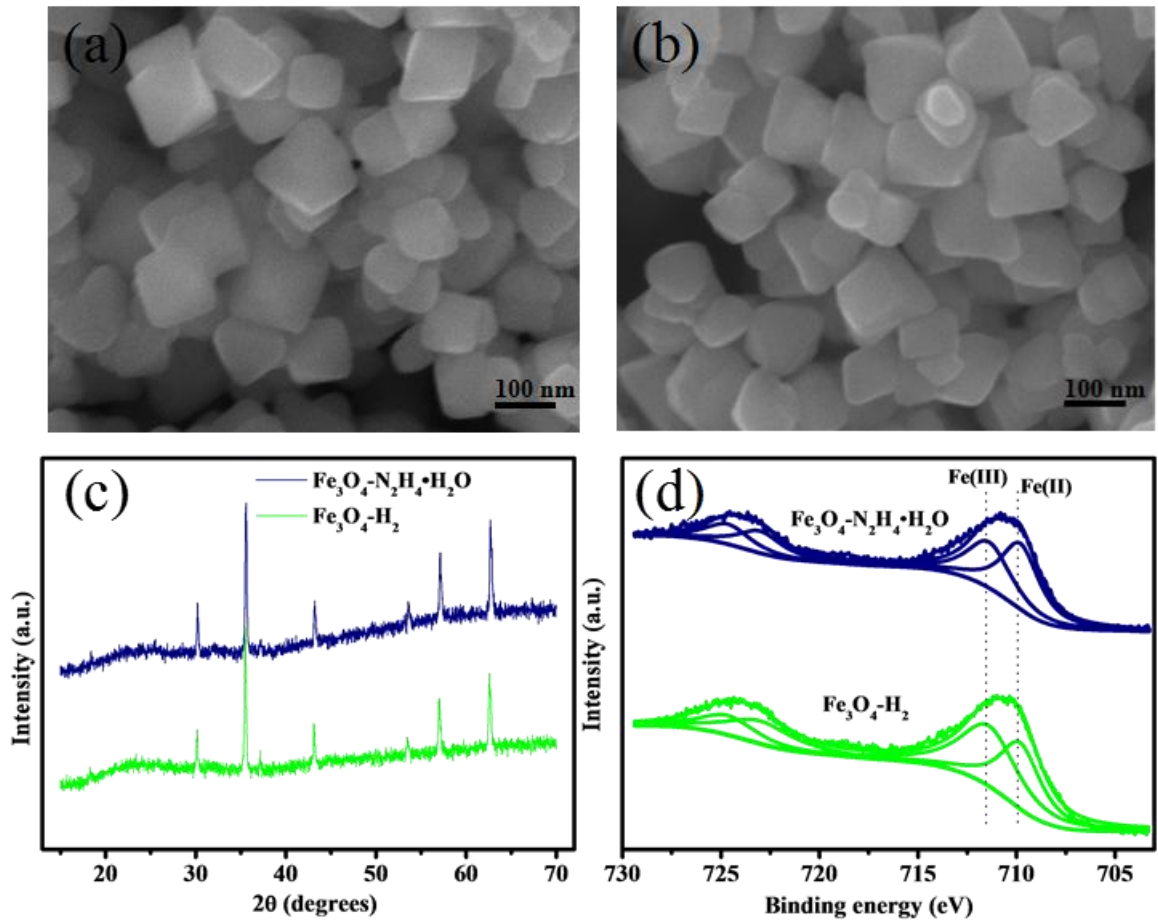

Figure 8.SEM images of $\mathrm{Fe}_{3} \mathrm{O}_{4}-\mathrm{H}_{2}$ (a), and $\mathrm{Fe}_{3} \mathrm{O}_{4}-\mathrm{N}_{2} \mathrm{H}_{4} \cdot \mathrm{H}_{2} \mathrm{O}$ (b);XRD patterns (c), and XPS spectra (d) of $\mathrm{Fe}_{3} \mathrm{O}_{4}-\mathrm{N}_{2} \mathrm{H}_{4} \cdot \mathrm{H}_{2} \mathrm{O}$ and $\mathrm{Fe}_{3} \mathrm{O}_{4}-\mathrm{H}_{2}$.

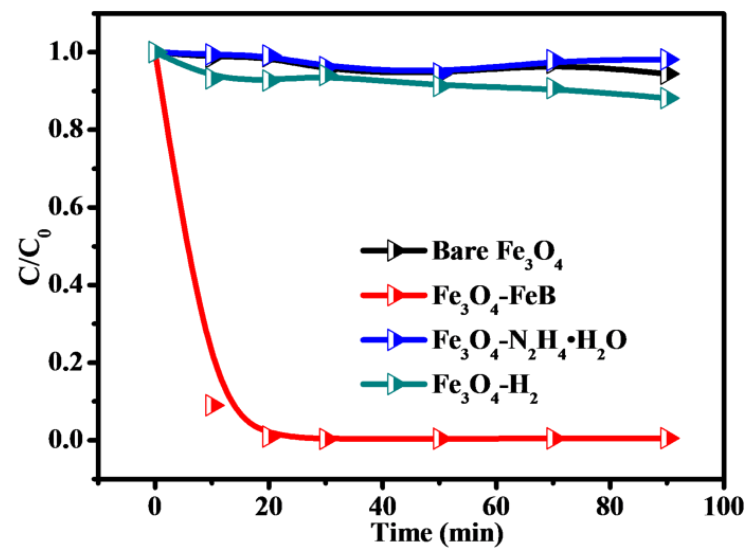

Figure 9. Time profile of $\mathrm{Cr}(\mathrm{VI})$ removal with $\mathrm{Fe}_{3} \mathrm{O}_{4}, \mathrm{Fe}_{3} \mathrm{O}_{4}-\mathrm{FeB}, \mathrm{Fe}_{3} \mathrm{O}_{4}-\mathrm{N}_{2} \mathrm{H}_{4} \cdot \mathrm{H}_{2} \mathrm{O}$, and $\mathrm{Fe}_{3} \mathrm{O}_{4}-\mathrm{H}_{2}$. 

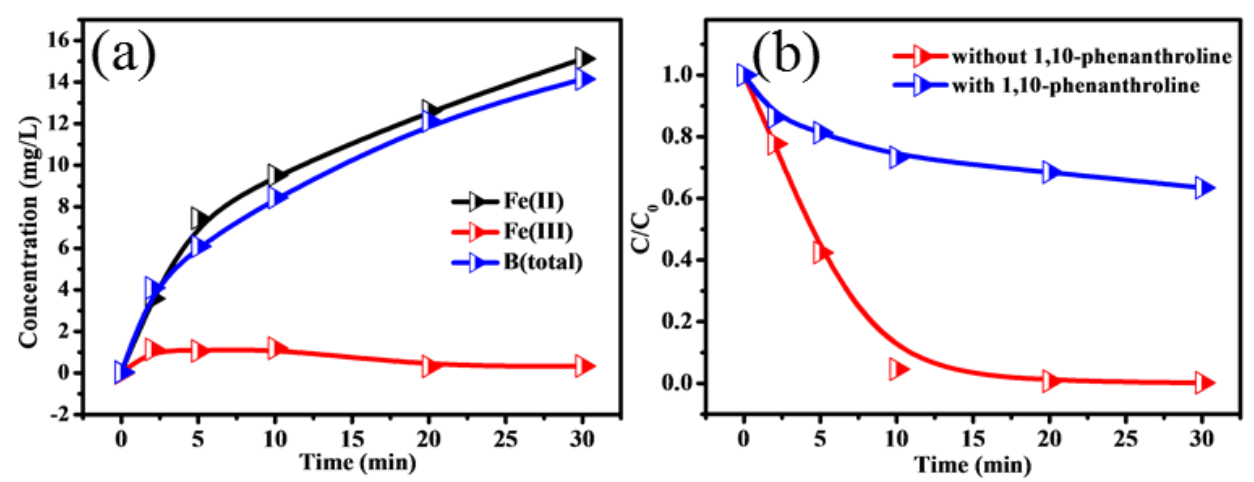

Figure 10. (a) Time profile of concentrations of B, Fe(II), and Fe(III) in solution; (b) time profile of $\mathrm{Cr}(\mathrm{VI})$ removal with $\mathrm{Fe}_{3} \mathrm{O}_{4}-\mathrm{FeB}$ in the absence or presence of 1,10-phenanthroline.
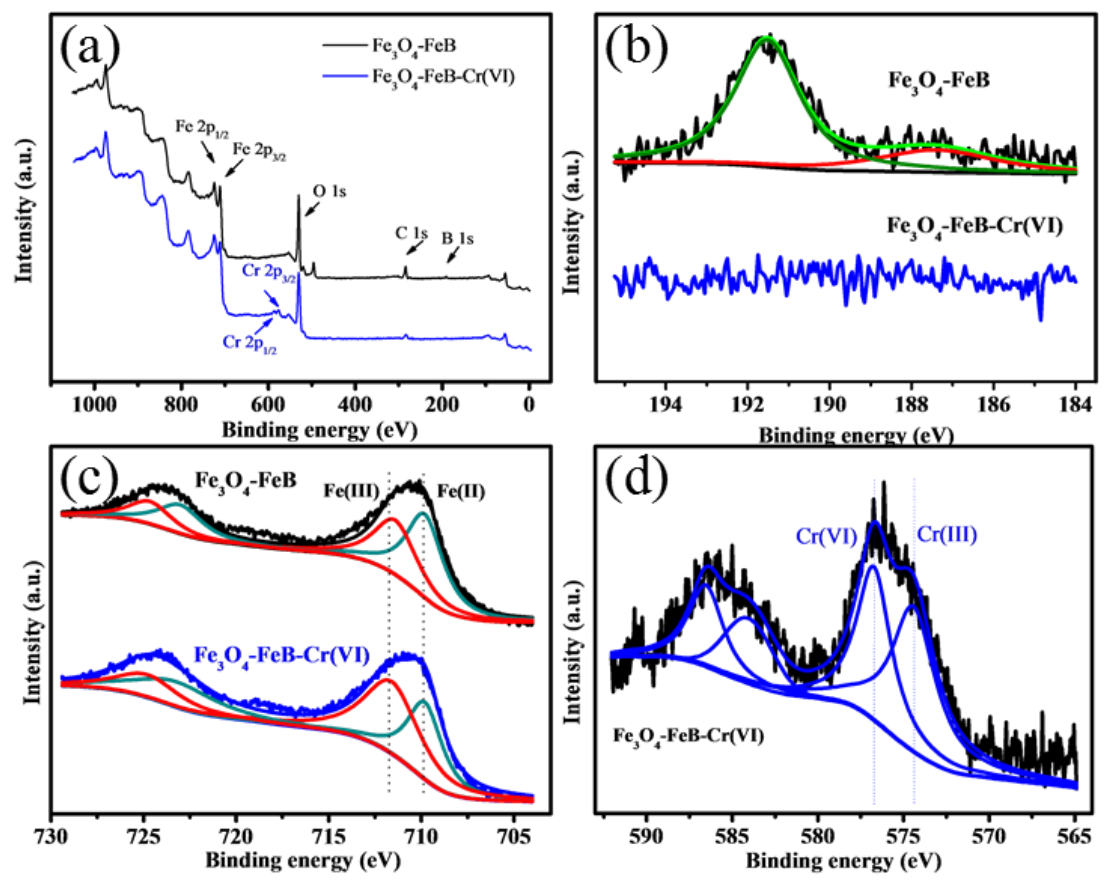

Figure 11. XPS spectra of $\mathrm{Fe}_{3} \mathrm{O}_{4}-\mathrm{FeB}$ before and after $\mathrm{Cr}(\mathrm{VI})$ removal, (a) XPS survey;(b) high resolution of $\mathrm{B}$ 1s; (c) high resolution of $\mathrm{Fe} \mathrm{2p}$; and (d) high resolution of $\mathrm{Cr} 2 \mathrm{p}$. 

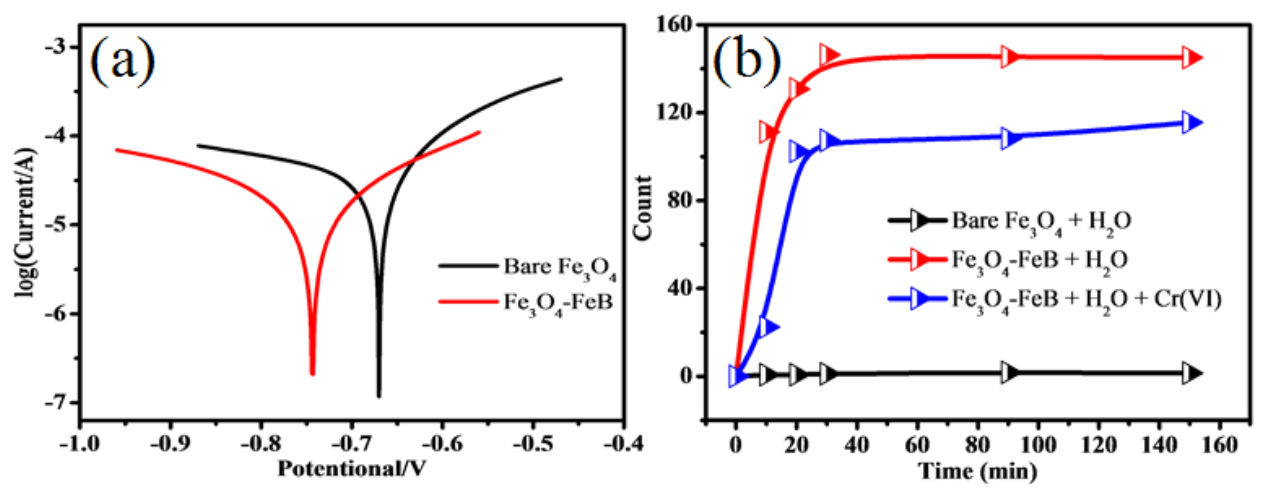

Figure 12. (a) Tafel plots; (b) temporal concentration change of hydrogen evolution of $\mathrm{Fe}_{3} \mathrm{O}_{4}$ and $\mathrm{Fe}_{3} \mathrm{O}_{4}-\mathrm{FeB}$ in the system.

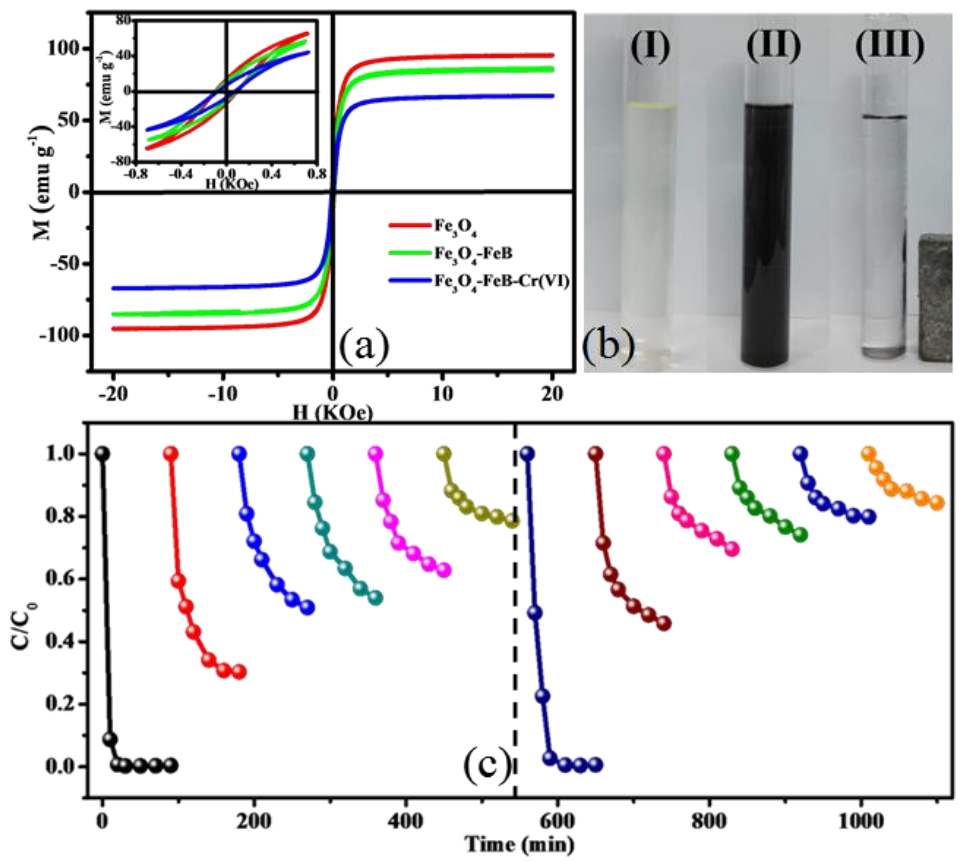

Figure 13. (a) Magnetic hysteresis loop measured at $300 \mathrm{~K}$, the enlarged magnetization curve between -800 and 800 Oe (inset); (b) photographs of magnetic separation: (I) $8 \mathrm{mg} \mathrm{L}^{-1} \mathrm{Cr}$ (VI); (II) a mixture of $\mathrm{Fe}_{3} \mathrm{O}_{4}-\mathrm{FeB}$ with $8 \mathrm{mg} \mathrm{L}^{-1} \mathrm{Cr}(\mathrm{VI})$ solution; (III) magnetic separation of $\mathrm{Fe}_{3} \mathrm{O}_{4}-\mathrm{FeB}$ from the solution;(c) Reusability of $\mathrm{Fe}_{3} \mathrm{O}_{4}-\mathrm{FeB}$ : left, $\mathrm{Fe}_{3} \mathrm{O}_{4}-\mathrm{FeB}$ recycled to the next removal without any treating; (b) the recycled solid was retreated by $\mathrm{NaBH}_{4}$ to the next removal. 


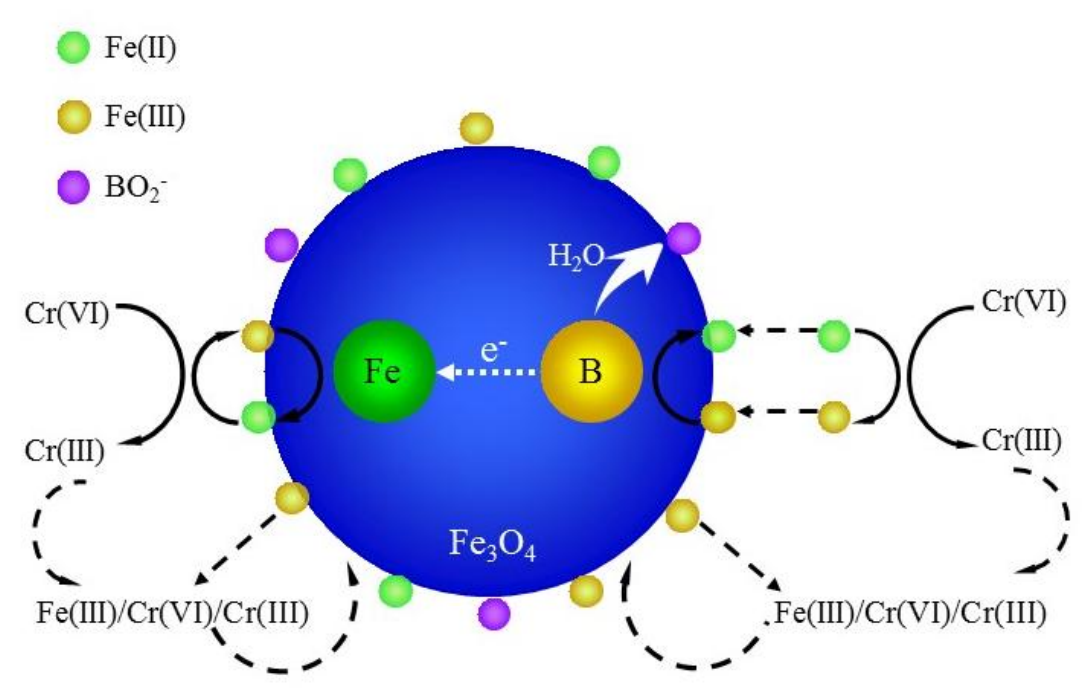

Scheme 1. Schematic $\mathrm{Cr}(\mathrm{VI})$ removal mechanism with $\mathrm{Fe}_{3} \mathrm{O}_{4}-\mathrm{FeB}$.

Table 1. Mössbauer spectrahyperfine parameters.

\begin{tabular}{|c|c|c|c|c|c|c|}
\hline & $\begin{array}{c}\delta \\
(\mathrm{mm} / \mathrm{s})\end{array}$ & $\begin{array}{c}\mathrm{Q} \\
(\mathrm{mm} / \mathrm{s})\end{array}$ & $\begin{array}{c}\mathrm{H} \\
(\mathrm{kOe})\end{array}$ & $\begin{array}{c}\text { Line width } \\
(\mathrm{mm} / \mathrm{s})\end{array}$ & $\begin{array}{l}\text { Area } \\
(\%)\end{array}$ & $\begin{array}{c}\text { Possible } \\
\text { assignment }\end{array}$ \\
\hline & 0.304 & -0.0058 & 488.13 & 0.2154 & 57.21 & Ordered iron(III)oxide \\
\hline $\mathrm{Fe}_{3} \mathrm{O}_{4}$ & 0.6594 & 0.0061 & 451.97 & 0.2512 & 42.79 & Ordered iron(II)oxide \\
\hline \multirow{6}{*}{ TreatedFe ${ }_{3} \mathrm{O}_{4}$} & 0.306 & -0.014 & 487.5 & 0.225 & 32.2 & Ordered iron(III) oxide \\
\hline & 0.652 & -0.017 & 453.6 & 0.243 & 27.0 & Ordered iron(II) oxide \\
\hline & 0.199 & -0.091 & 156.2 & 1.831 & 35.3 & Ordered iron(III)oxide \\
\hline & -0.560 & -0.106 & 230.4 & 0.104 & 1.1 & $\mathrm{Fe}_{\mathrm{x}} \mathrm{B}_{1-\mathrm{x}}$ \\
\hline & 0.924 & 1.965 & & 0.118 & 1.4 & High-spin iron(II) \\
\hline & 0.211 & 1.106 & & 0.217 & 3.1 & High-spin iron(III) \\
\hline
\end{tabular}

* isomer shift $\delta$, quadrupolar splitting $\mathrm{Q}$, and hyperfine filed $\mathrm{H}$ 
Table 2. Ratio of $\mathrm{Fe}^{\mathrm{II}} / \mathrm{Fe}_{\text {total }}$ and $\mathrm{Fe}^{\mathrm{III}} / \mathrm{Fe}_{\text {total }}$ in $\mathrm{Fe} 2 \mathrm{p}$ core level spectra, and ratio of $\mathrm{B}$ in oxides to total $\left(\mathrm{B} / \mathrm{B}_{\text {total }}\right)$ of the $\mathrm{Fe}_{3} \mathrm{O}_{4}, \mathrm{Fe}_{3} \mathrm{O}_{4}-\mathrm{FeB}, \mathrm{Fe}_{3} \mathrm{O}_{4}-\mathrm{H}_{2}$, and $\mathrm{Fe}_{3} \mathrm{O}_{4}-\mathrm{N}_{2} \mathrm{H}_{4} \cdot \mathrm{H}_{2} \mathrm{O}$ samples.

\begin{tabular}{cccc}
\hline & $\mathrm{Fe}^{\mathrm{II}} / \mathrm{Fe}_{\text {total }}$ & $\mathrm{Fe}^{\mathrm{III}} / \mathrm{Fe}_{\text {total }}$ & $\mathrm{B} / \mathrm{B}_{\text {total }}(\%)$ \\
\hline $\mathrm{Fe}_{3} \mathrm{O}_{4}$ & 0.395 & 0.605 & - \\
$\mathrm{Fe}_{3} \mathrm{O}_{4}-\mathrm{FeB}$ & 0.570 & 0.430 & 1.82 \\
$\mathrm{Fe}_{3} \mathrm{O}_{4}-\mathrm{H}_{2}$ & 0.486 & 0.514 & - \\
$\mathrm{Fe}_{3} \mathrm{O}_{4}-\mathrm{N}_{2} \mathrm{H}_{4} \cdot \mathrm{H}_{2} \mathrm{O}$ & 0.546 & 0.454 & - \\
$\mathrm{Fe}_{3} \mathrm{O}_{4}-\mathrm{FeB}-\mathrm{Cr}(\mathrm{VI})$ & 0.358 & 0.642 & 0.029 \\
\hline
\end{tabular}

Table 3. Theoretical and calculatedq $\mathrm{e}_{\mathrm{e}}$ values, $\mathrm{k}_{2}$, and $\mathrm{R}^{2}$.

\begin{tabular}{cccc}
\hline & $\begin{array}{c}\text { Calculated } \mathrm{q}_{\mathrm{e}} \\
\left(\mathrm{mg} \mathrm{L}^{-1}\right)\end{array}$ & $\begin{array}{c}\mathrm{k}_{2} \\
\left(\mathrm{~g} / \mathrm{mg}^{-1} \mathrm{~min}^{-1}\right)\end{array}$ & $\mathrm{R}^{2}$ \\
\hline 4 & 5.01 & 0.371 & 0.999 \\
8 & 10.04 & 0.211 & 0.999 \\
16 & 20.53 & 0.023 & 0.999 \\
32 & 42.59 & 0.002 & 0.998 \\
\hline
\end{tabular}


Table 4. Cr(VI) removal capacities of various adsorbents.

\begin{tabular}{|c|c|c|c|}
\hline Adsorbents & $\mathrm{pH}$ & $\begin{array}{c}\mathrm{q}_{\max } \\
(\mathrm{mg} / \mathrm{g})\end{array}$ & Ref \\
\hline $\mathrm{Fe}_{3} \mathrm{O}_{4}-\mathrm{FeB}$ & 6.3 & 38.9 & This work \\
\hline $\mathrm{nZVI}-\mathrm{Fe}_{3} \mathrm{O}_{4}$ & 3 & 100 & 5 \\
\hline Magnetic Nanoparticles $\left(\mathrm{Fe}_{3} \mathrm{O}_{4}\right)$ & 6 & 3.5 & 7 \\
\hline Nanoscale maghemite $\left(\mathrm{Fe}_{2} \mathrm{O}_{3}\right)$ & $2-3$ & 19.2 & 8 \\
\hline Polypyrrole magnetic nanocomposite & 2 & $169-264$ & 9 \\
\hline Ethylenediamine-functionalized $\mathrm{Fe}_{3} \mathrm{O}_{4}$ magnetic polymers & 2 & 60 & 10 \\
\hline $\mathrm{HA}-\mathrm{Fe}_{3} \mathrm{O}_{4}$ & $4-10$ & 3.37 & 11 \\
\hline Reduced graphene oxide- $-\mathrm{Fe}_{3} \mathrm{O}_{4}$ magnetic composites & 3 & 293 & 12 \\
\hline
\end{tabular}

Table 5. Langmuir and Freundlich isotherm parameters for $\mathrm{Cr}(\mathrm{VI})$ removal by $\mathrm{Fe}_{3} \mathrm{O}_{4}-\mathrm{FeB}$.

\begin{tabular}{ccccccc}
\hline $\mathrm{Cr}(\mathrm{VI})$ & \multicolumn{3}{c}{ Langmuir isotherm } & \multicolumn{3}{c}{ Freundlich isotherm } \\
\cline { 2 - 6 } $\mathrm{mg} \cdot \mathrm{L}^{-1}$ & $\mathrm{Q}^{0}$ & $K$ & $\mathrm{R}^{2}$ & $\mathrm{~K}_{\mathrm{f}}$ & $\mathrm{n}$ & $\mathrm{R}^{2}$ \\
& $\left(\mathrm{mg} \cdot \mathrm{g}^{-1}\right)$ & $\left({\left.\mathrm{L} \cdot \mathrm{mg}^{-1}\right)}\right.$ & & $\left({\left.\mathrm{mg} \cdot \mathrm{g}^{-1}\right)}\left({\left.\mathrm{L} \cdot \mathrm{mg}^{-1}\right)}\right.\right.$ & \\
\hline 4 & 4.56 & 401.5 & 0.99 & 4.47 & 34.81 & 0.91 \\
8 & 9.09 & 376.0 & 0.99 & 9.08 & 35.71 & 0.94 \\
16 & 15.29 & 23.1 & 0.99 & 17.34 & 19.67 & 0.73 \\
32 & 19.79 & 5.9 & 0.99 & 42.07 & 4.81 & 0.79 \\
\hline
\end{tabular}


Graphical Abstract (for review)

\section{Graphical Abstract}

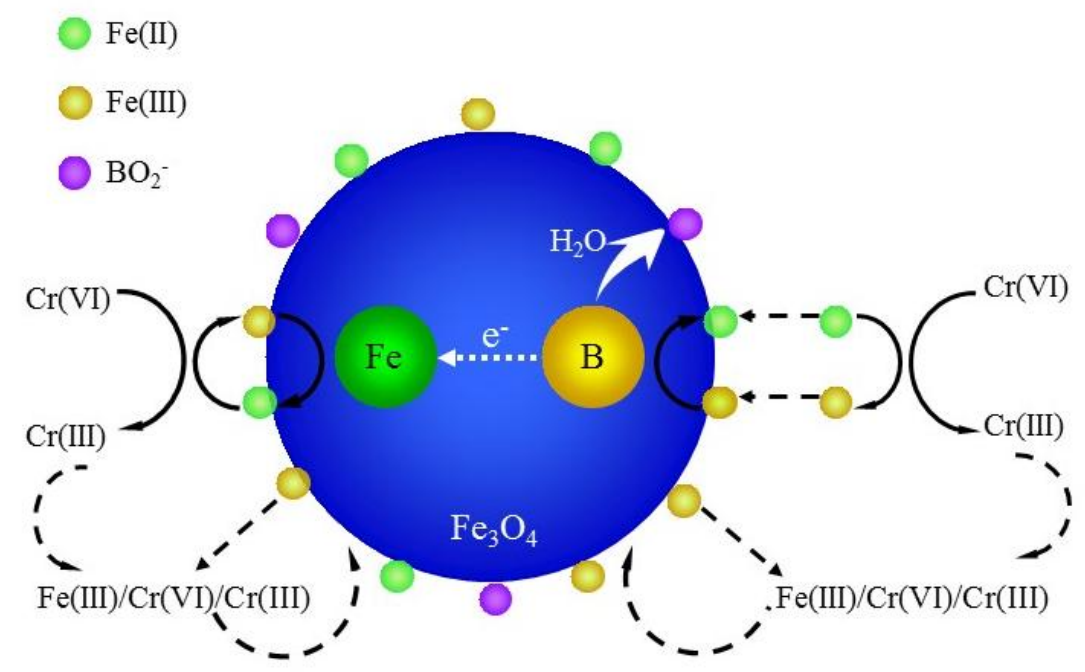

